UNIVERSIDADE DE SÃO PAULO

INSTITUTO DE RELAÇÕES INTERNACIONAIS

THAIS SILVA MENEZES

DIREITOS HUMANOS E REFÚGIO: A VIOLAÇÃO DE DIREITOS ANTES E APÓS A DETERMINAÇÃO DO STATUS DE REFUGIADO 
THAIS SILVA MENEZES

\section{DIREITOS HUMANOS E REFÚGIO: A VIOLAÇÃO DE DIREITOS ANTES E APÓS A DETERMINAÇÃO DO STATUS DE REFUGIADO}

Dissertação apresentada ao Instituto de Relações Internacionais da Universidade de São Paulo para obtenção do título de Mestre em Ciências - Programa de Pós-Graduação em Relações Internacionais

Orientadora: Profa. Dra. Rossana Rocha Reis 


\section{DIREITOS HUMANOS E REFÚGIO: A VIOLAÇÃO DE DIREITOS ANTES E APÓS A DETERMINAÇÃO DO STATUS DE REFUGIADO}

Dissertação apresentada ao Instituto de Relações Internacionais da Universidade de São Paulo, para obtenção do título de Mestre em Ciências - Programa de Pós-Graduação em Relações Internacionais.

\section{BANCA EXAMINADORA}

Presidente

Orientadora: Profa. Dra. Rossana Rocha Reis (USP)

Prof. Dr.

Instituição

Assinatura

Prof. Dr.

Instituição Assinatura

São Paulo, de de 2012 . 
À minha família, sempre meu porto seguro. 


\section{AGRADECIMENTOS}

Agradeço a meus pais, Sival e Giltania, por todo o apoio e por acreditarem sempre em mim. Por terem me ensinado que o que move as pessoas são os sonhos, por me ensinarem a traçar os meus sonhos e ter como objetivo na vida buscar sua concretização.

Ao meu irmão, Victor, por sua amizade e ombro amigo nos momentos difíceis e por seu braço, ritmo e condução no forró.

Aos meus familiares, por toda a energia positiva enviada - mesmo de tão longe - para que eu sempre continue a minha jornada.

A Joana Santos, por todo o apoio que tornou possível a minha vida em São Paulo; e a Carla Almeida e Cloud Viel, pelos momentos compartilhados ao longo desses dois anos e meio convivendo a cada dia.

A Tchella Fernandes e a Adriana Capuano, pela ajuda com o projeto de mestrado e pela amizade que supera a distância.

A Taiana Araújo, por ter se tornado minha irmã nesse último ano, por termos construído juntas uma relação que supera a amizade para se tornar quase uma complementaridade.

A Tiago Xavier, por estar na minha vida há tanto tempo me fazendo tão bem.

Aos colegas e amigos da Pós-Graduação, Allexandro Coelho, Cícero Luz, Danylo Rocha, Flávio Pinheiro, Flávio Pedroso e Nora Rachman, por todas as animadas happy hours; e, em especial a Ítalo Sposito, Marina Martins, José Mauro Delella, Iagê Miola, Camila Baraldi, Flávia Donadelli, Isabel Marcondes, Izabela Araújo, Augusto Leão e Lucas Tasquetto por terem desmontado a selva de pedras e tornado São Paulo um lugar mais aconchegante.

Ao José Roberto Porto, pelo apoio no projeto, na qualificação, mas, sobretudo por ter sido meu suporte nos momentos difíceis e por tudo que compartilhamos nesses cinco anos.

A Rossana Rocha Reis, minha orientadora, por me guiar nessa busca de conhecimento, conseguindo extrair o meu melhor. Sem dúvida, a qualidade dessa pesquisa é resultado de suas pertinentes considerações.

Ao Bruno Comparato, pelas preciosas considerações que me levaram a aprimorar a pesquisa.

Ao João Paulo Cândia Veiga, pelos momentos compartilhados em sala de aula e pelas considerações que mudaram minha forma de ver meu tema de pesquisa.

À Fundação de Amparo à Pesquisa do Estado de São Paulo - Fapesp - pelo financiamento fundamental.

Eis aqui o resultado da congregação de tantas energias positivas. Eis mais um sonho que se concretiza. Obrigada. 
“... para cada refugiado existe sempre um nãorefugiado que poderia ser um refugiado caso fossem diferentes as circunstâncias $e$ prioridades políticas." 


\section{RESUMO}

MENEZES, Thais S. Direitos humanos e refúgio: a violação de direitos antes e após a determinação do status de refugiado. 2012. 60 f. Dissertação (Mestrado) - Instituto de Relações Internacionais, Universidade de São Paulo, São Paulo, 2012.

Dada sua definição e a forma como opera na atualidade, o refúgio pode ser caracterizado por dois momentos: o anterior à determinação do status de refugiado - o qual congrega as condições de vida que levam à fuga e legitimam o reconhecimento como refugiado -; e o posterior - o qual consiste das condições de vida no país de acolhida (a chamada fase de proteção). $\mathrm{O}$ instituto do refúgio vincula dois âmbitos que visam garantir a proteção internacional do indivíduo: o regime internacional dos direitos humanos e o regime internacional dos refugiados. Atualmente, tem-se reconhecido a relação entre essas duas esferas, principalmente no que se refere à aproximação histórica e filosófica, contudo, ainda há posicionamentos que defendem a não-existência de tal vinculação. Esse trabalho visa desenvolver uma análise sobre a relação existente entre direitos humanos e refúgio nos momentos anterior e posterior à determinação do status de refugiado. Em relação ao primeiro, visando demonstrar a impossibilidade de desvinculação entre a concepção contemporânea da proteção internacional dos refugiados e o reconhecimento e a garantia dos direitos humanos, argumenta-se, a partir de uma revisão bibliográfica, que a violação de direitos humanos é sempre o motivo que leva à determinação da condição de refugiado. No que concerne ao segundo, visamos analisar como o ACNUR, principal organismo para o trato da questão, tem se manifestado em relação aos direitos humanos dos refugiados nos países de acolhida partindo do exame de algumas de suas publicações e apontando como a política internacional tem se configurado como fator central para a forma como o ACNUR se expressa em relação à violação desses direitos nos países de refúgio.

Palavras-chave: Regime internacional dos refugiados. Direitos humanos. Violação de direitos humanos. ACNUR. Política internacional. 


\begin{abstract}
MENEZES, Thais S. Human rights and refugees: the human rights violation before and after the refugee status determination. 2012. $60 \mathrm{f}$. Dissertação (Mestrado) - Instituto de Relações Internacionais, Universidade de São Paulo, São Paulo, 2012.

Given its definition and the way it operates in the present, the refuge can be characterized by two moments: the one before the refugee status determination process - which comprises the life conditions that lead to the flight and justify the admission of a refugee in another country -; and the one after this process - which consists of the life conditions in the asylum country (the so-called protection phase). The refuge bonds two domains which aim to assure the international protection: the human rights international regime and the refugee international regime. Presently, it has been recognized that there is a fundamental tie between these two spheres, mainly in relation to the historical and philosophical approximation, nevertheless, there still are opinions which advocates against such linking. This research aims to develop an analysis about the relation that exists between human rights and refuge in the moments before and after the refugee status determination. In respect to the first, aiming to demonstrate the impossibility of disconnecting the contemporaneous concept of international protection and the recognition and guarantee of human rights, starting from a bibliographic review, it is argued that the human rights violation is always the reason that yields to the refugee status determination. Regarding the second one, we aim to analyze how the UNHCR, main organization for dealing with the issue, has manifested its opinions about the refugee human rights in the asylum countries - using as parameter some of its publications and revealing how the world politics has been a key factor to the way this agency expresses itself respecting to the rights violations in the asylum countries.
\end{abstract}

Keywords: Refugee international regime. Human rights. Human rights violation. UNHCR. World politics. 


\section{SUMÁRIO}

\section{Artigo 1 DIREITOS HUMANOS E REFÚGIO: UMA ANÁLISE SOBRE O MOMENTO ANTERIOR À DETERMINAÇÃO DO STATUS DE REFUGIADO}

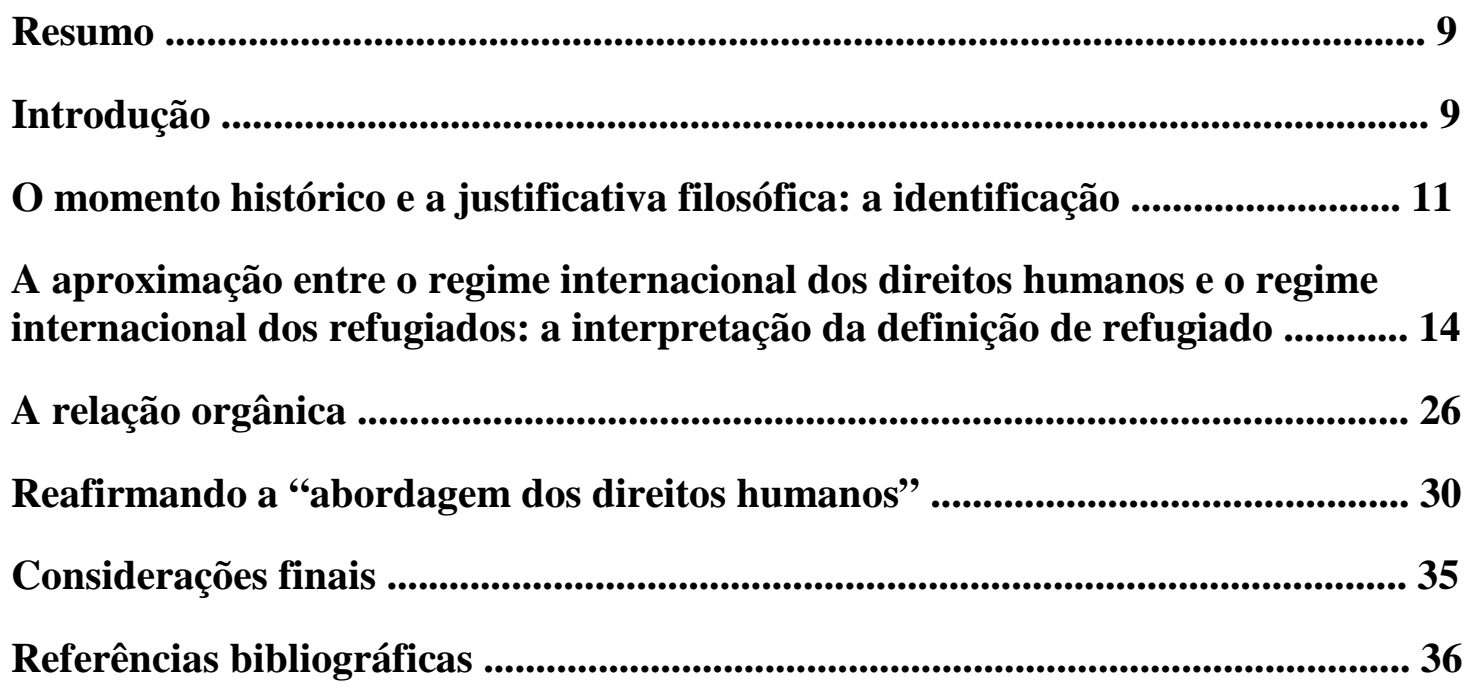

\section{Artigo 2 DIREITOS HUMANOS E REFÚGIO: UMA ANÁLISE SOBRE O MOMENTO PÓS-DETERMINAÇÃO DO STATUS DE REFUGIADO}

Resumo

Introdução

ACNUR e direitos humanos: o reconhecimento do status de refugiado e a proteção em países de acolhida 41

ACNUR e direitos humanos: a proteção nos países de acolhida ............................... 44

Anuários Estatísticos ................................................................................................ 44

Apelos Globais ................................................................................................... 47

Irã ……................................................................................................................ 47

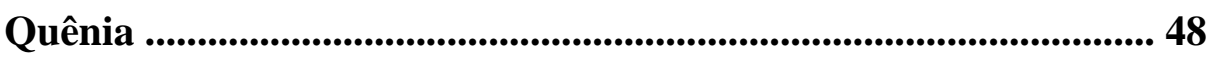

Alemanha .............................................................................................. 48

O papel da política internacional ....................................................................................... 53

Considerações finais .................................................................................................................. 57

Referências bibliográficas .................................................................................................. 58 


\title{
DIREITOS HUMANOS E REFÚGIO: UMA ANÁLISE SOBRE O MOMENTO ANTERIOR À DETERMINAÇÃO DO STATUS DE REFUGIADO
}

\begin{abstract}
Resumo
O instituto do refúgio vincula dois âmbitos que visam garantir proteção à pessoa humana, representados pelo regime internacional dos direitos humanos e o regime internacional dos refugiados. Durante muito tempo essas duas esferas de proteção ao indivíduo foram tratadas separadamente, devido a um entendimento equivocado de uma dissociação histórica ou material entre as mesmas. Atualmente, tem-se reconhecido a relação entre essas duas temáticas, no entanto, ainda existem posicionamentos que advogam contra essa vinculação, refletidos, principalmente, nas decisões sobre casos de determinação do status de refugiado, nos âmbitos nacionais. Esse trabalho visa demonstrar a impossibilidade de desvinculação entre a concepção contemporânea da proteção internacional aos refugiados e o reconhecimento e a garantia dos direitos humanos, por serem essas duas temáticas intrinsecamente vinculadas, tanto histórica e filosófica quanto organicamente. Nesse sentido, trabalha-se com a hipótese de que a violação de direitos humanos - devido a raça, religião, nacionalidade, opinião política ou pertencimento a grupo social - é sempre o critério a ser utilizado para se determinar a necessidade de proteção internacional.
\end{abstract}

Palavras-chave: Regime internacional dos refugiados. Direitos humanos. Perseguição. Violação de direitos humanos.

\section{Introdução}

Desde a criação do sistema de Estados na Paz de Vestifália, passando pelas duas guerras mundiais, pela descolonização e criação da sociedade internacional pós II Guerra Mundial, pela bipolaridade da Guerra Fria, e pela emergência de novas ameaças transnacionais ligadas ao terrorismo e ao meio ambiente, os refugiados têm sido uma constante na política internacional (BETTS; LOESCHER, 2011). A centralidade dessa temática na atualidade se justifica pela expressividade do fenômeno do refúgio (a existência de 15,2 milhões de refugiados), sua localização entre a política doméstica e a internacional (como um país lida com a questão leva a consequências para os outros e influencia suas relações) e sua relação com o sistema internacional (os fluxos de refugiados resultam de várias mudanças sociais e políticas dentro de uma estrutura política mais ampla). Da mesma forma, o dinamismo do regime internacional dos refugiados ressalta a importância contínua do tema para a comunidade internacional (HADDAD, 2008). 
O regime internacional dos refugiados é definido como o conjunto de normas, leis e instituições desenhado para proteger e assistir os migrantes forçados que cruzaram uma fronteira internacional devido ao medo de perseguição (ROGERS, 1992) ou devido a conforme instrumentos regionais - violência generalizada em seus próprios países, agressão estrangeira, conflitos internos ou violação massiva de direitos humanos. Esse mecanismo tem como base a definição de refugiado presente na Convenção Relativa ao Estatuto do Refugiado, de $1951^{1}$ (parcialmente alterada por seu Protocolo Relativo de 1967²); sendo, ainda, configurado pela atuação do Alto Comissariado das Nações Unidas para os Refugiados (ACNUR), de organizações não-governamentais nacionais e internacionais, assim como dos Estados que aderiram ou agem de acordo com os instrumentos internacionais que versam sobre a questão.

O instituto do refúgio que vige na atualidade, portanto, resulta de uma concertação internacional que compreendeu ser a cooperação internacional o modo mais adequado para lidar com esse tipo de migração internacional forçada. Dada a sua definição e a forma como opera na atualidade, esse instituto pode ser caracterizado por dois momentos: o momento anterior ao reconhecimento do status de refugiado - o qual congrega as condições de vida que levaram à fuga e que legitimam o emprego desse instituto de proteção internacional da pessoa -, e o momento posterior ao reconhecimento - a chamada "fase de proteção", ou seja, a vida do refugiado em seu país de acolhida.

O presente trabalho debate a relação entre a temática do refúgio e a questão dos direitos humanos referente ao momento anterior ao reconhecimento da condição de refugiado, enfocando a justificativa filosófica para a existência do refúgio e, também, o momento histórico em que o mesmo emerge enquanto instituto jurídico e político global. Discutimos a hipótese de que é sempre uma violação de direitos humanos - relacionada a considerações de raça, religião, nacionalidade, opinião política ou pertencimento a grupo social - o critério utilizado para se determinar a necessidade de proteção internacional. Assim sendo, consideramos impossível desvincular a concepção contemporânea da proteção aos refugiados e o reconhecimento e a garantia dos direitos humanos. Em outras palavras, a dinâmica do refúgio no mundo contemporâneo apóia-se essencialmente em considerações fundadas em

\footnotetext{
${ }^{1}$ Doravante referida como "Convenção de 1951" ou "Convenção".

${ }^{2}$ Segundo os quais é refugiada a pessoa "que temendo ser perseguida por motivos de raça, religião, nacionalidade, grupo social ou opiniões políticas, se encontra fora do país de sua nacionalidade e que não pode ou, em virtude desse temor não quer valer-se da proteção desse país, ou que, se não tem nacionalidade e se encontra fora do país no qual tinha sua residência habitual, não pode ou, devido ao referido temor, não quer voltar a ele." (ONU, 1951)
} 
ideias de direitos humanos. Acreditamos que em um contexto no qual se levanta constantemente a ideia da existência de uma crise da proteção internacional à pessoa, entender os fundamentos que alicerçam esse instituto é importante para uma melhor compreensão do fenômeno, o que possibilita a proposição de respostas mais adequadas e eficientes.

\section{O momento histórico e a justificativa filosófica: a identificação}

O regime de proteção aos refugiados começou a ser formulado no período entre guerras, tendo se consolidado após 1945 ao lado do campo dos direitos humanos internacionais (HADDAD, 2008). O momento histórico em que esse regime se consolidou aquele de ampla afirmação internacional de direitos humanos - é ressaltado por diversos autores da literatura sobre o refúgio. Foster (2007) afirma que, considerando a referência no preâmbulo da Convenção de 1951 à Declaração Universal de Direitos Humanos (DUDH), essa pode ser considerada parte integrante do Direito Internacional dos Direitos Humanos (DIDH). A Convenção constitui, assim, parte do movimento internacional dos direitos humanos que começou no meio do século XX e se expandiu desde então. Igualmente, Steinbock (1998) identifica a Convenção de 1951 - assim como o Protocolo de 1967 - como um instrumento internacional de direitos humanos. Mais especificamente, esse autor declara que prover uma reparação tangível para certas violações de direitos humanos torna esses documentos dois dos principais instrumentos de direitos humanos. É, assim, a definição de refugiado da Convenção um produto e uma parte constituinte da história do século XX (STEINBOCK, 1998) - uma história marcada, no que se refere à proteção dos indivíduos, pelo reconhecimento internacional de direitos humanos.

A aproximação histórica, assim, não constitui mera coincidência. Sem dúvida, a configuração atual do regime dos refugiados constituiu-se como resultado e, ao mesmo tempo, como parte da afirmação internacional de direitos humanos que ocorreu após a II Guerra Mundial, essencialmente influenciada pelos acontecimentos ocorridos durante esse período de conflito e buscando evitar que situações de amplo desrespeito à dignidade da pessoa humana viessem a se repetir. Como destaca Jackson (1991), o espírito existente durante a formulação da Convenção de 1951 era um verdadeiramente humanitário. Esse autor nota que existia um desejo genuíno de se criar um mundo melhor no qual os horrores da II Guerra Mundial não pudessem ocorrer novamente. Logo, já que o mundo permanecia imperfeito, devia ser assegurado, ao menos, que as vítimas de opressão e perseguição 
obrigadas a deixar seu país como refugiadas fossem decentemente tratadas pela comunidade internacional (JACKSON, 1991).

A compreensão desse vínculo filosófico entre refúgio e direitos humanos é exemplificada pelas palavras de Jubilut:

\begin{abstract}
A proteção internacional dos refugiados se opera mediante uma estrutura de direitos individuais e responsabilidade estatal que deriva da mesma base filosófica que a proteção internacional dos direitos humanos. O Direito Internacional dos Direitos Humanos é a fonte dos princípios de proteção dos refugiados e ao mesmo tempo complementa tal proteção. (JUBILUT, 2007, p. 60).
\end{abstract}

Essa autora explicita que ambas vertentes de proteção internacional da pessoa partem do mesmo fundamento, se distinguindo quanto a suas abrangências, já que o Direito Internacional dos Refugiados (DIR) protege o ser humano perseguido em função de sua raça, religião, nacionalidade, opinião política e pertencimento a grupo social, enquanto o DIDH objetiva também assegurar condições mínimas para que o homem sobreviva e possa buscar felicidade. Dessa forma, pode-se dizer que o último engloba a base de atuação do primeiro. Jubilut, traçando um paralelo entre esses dois âmbitos de proteção explica

\begin{abstract}
Desse modo, tem-se que o Direito Internacional dos Direitos Humanos e o Direito Internacional dos Refugiados apresentam o mesmo objeto - a proteção da pessoa humana na ordem internacional; o mesmo método - regras internacionais a fim de assegurar essa proteção; os mesmos sujeitos - o ser humano enquanto beneficiário e o Estado enquanto destinatário e obrigado principal das regras; os mesmos princípios e finalidades - a dignidade da pessoa humana, [...], a garantia do respeito a esta e, consequentemente, a não-discriminação, diferindo apenas no conteúdo de suas regras, em função de seu âmbito de aplicação. Por essa razão, pode-se defender a tese de que se trata de ramos assemelhados do direito, sendo que o Direito Internacional dos Direitos Humanos, por ter uma maior aplicabilidade e um escopo de proteção mais alargado, engloba as garantias mais específicas do Direito Internacional dos Refugiados. (JUBILUT, 2007, p. 60).
\end{abstract}

Loescher e Milner (2003) apontam outro aspecto da vinculação entre refúgio e direitos humanos ao afirmarem que, embora seja garantida aos Estados a prerrogativa de controlar a entrada de pessoas e reforçar fronteiras, eles também são constrangidos por instrumentos legais internacionais sobre refugiados e direitos humanos a fazê-lo sem infringir o direito de pessoas em necessidade de proteção de buscar asilo. Isso aponta para o "direito de asilo", reconhecido na DUDH, que afirma - no artigo $14^{\circ}$ - que "Todo ser humano, vítima de perseguição, tem o direito de procurar e gozar asilo em outros países.” (ONU, 1948). Segundo Jubilut (2007), o refúgio fundamenta-se em tal declaração de direito, o qual visa à proteção da pessoa humana frente à sua falta no território de origem ou residência habitual ${ }^{3}$.

\footnotetext{
${ }^{3} \mathrm{Na}$ atualidade, os termos asilo e refúgio ora são utilizados como sinônimos (na maioria dos casos), ora
} 
Haddad (2008) também aponta o artigo $14^{\circ}$ da DUDH como demonstração de que o Direito Internacional dos Refugiados é uma parte inseparável do código de direitos humanos. Essa autora ressalta que os refugiados são o efeito colateral do estabelecimento de Estados soberanos quando estes falham em garantir proteção a todos os seus cidadãos. As normas de direitos humanos evoluíram para evitar o teórico poder infinito e potencialmente destrutivo da soberania, o qual é responsável, em parte, pela criação de fluxos de refugiados. Haddad destaca, assim, os refugiados como uma categoria de pessoas cujos certos direitos humanos estão sob ameaça. Haddad nos direciona, dessa forma, a um aspecto fundamental da relação explorada nesse artigo: a existência de uma conexão entre violação de direitos humanos e refúgio.

Ibhawoh (2003) observa que durante muitos anos existiu nos círculos acadêmicos e de decisão política uma clara dicotomia entre os âmbitos dos direitos humanos e dos refugiados. Isso porque enquanto a primeira esfera se preocupava com os abusos aos direitos dos cidadãos por seus próprios governos ou instituições, o campo dos refugiados entrava em cena somente depois que pessoas fugindo de perseguição cruzavam fronteiras. No entanto, conforme Ibhawoh (2003), as últimas décadas têm testemunhado um progressivo entrelaço entre as linhas tradicionais dos estudos sobre os refugiados e o discurso dos direitos humanos. Nesse contexto, a admissão de solicitantes de asilo, seu tratamento e a concessão do status de refugiado tornaram-se elementos cruciais do sistema internacional para a proteção dos direitos humanos (IBHAWOH, 2003).

Em perspectiva similar, Jubilut (2007) assevera que entre as peculiaridades que relacionam o tema dos direitos humanos e o do refúgio se destaca o fato de ser o refúgio aplicado quando se verificam fortes violações de direitos humanos, conflitos armados ou guerras. A mesma interpretação é verificada na abordagem de diversos autores, como em Loescher (2009), que afirma que violações de direitos humanos e fluxos de refugiados andam de mãos dadas; em Cançado Trindade (1999), que sustenta haver uma interrelação entre o problema dos refugiados e os direitos humanos desde as causas principais do fluxo (quais sejam as violações de direitos humanos) e em Crisp (2000), que assevera que um dos propósitos do Direito Internacional dos Refugiados é proteger pessoas forçadas a deixarem seu país como resultado de perseguição, conflito armado e violações de direitos humanos.

denotam institutos diferentes (âmbito latinoamericano), sendo a distinção principal ser o refúgio um instituto internacionalmente estabelecido e o asilo uma expressão da discricionariedade estatal. Dada a preponderância dessa interpretação, assim como a similaridade de propósitos - a proteção internacional - utilizamos tais termos intercambiavelmente. Para discussão a respeito das diferenças vide BARRETO, 2006 e JUBILUT, 2007. 
O reconhecimento de que refúgio e direitos humanos são histórica - consolidaram-se no mesmo período histórico - e filosoficamente - ambos buscam a proteção da pessoa humana - vinculados é destacado por diversos autores ${ }^{4}$. Parece, portanto, ponto pacífico na literatura o entendimento de que a configuração do regime contemporâneo dos refugiados resultou da situação de intenso deslocamento forçado derivado dos conflitos da II Guerra Mundial e emergiu como resultado do (e integrando o) amplo reconhecimento internacional de direitos humanos. Todavia, o reconhecimento da existência desse elo não é consensual no que diz respeito à análise de outros aspectos do regime internacional dos refugiados, como no que concerne à violação de direitos humanos como caracterizadora da perseguição.

\section{A aproximação entre o regime internacional dos direitos humanos e o regime internacional dos refugiados: a interpretação da definição de refugiado.}

Se por um lado, como explorado acima, a literatura recorrentemente admite a relação entre refúgio e direitos humanos nos planos filosófico e histórico, não se pode observar a mesma concordância no que se refere à aproximação entre os dois regimes objetivando uma proteção mais ampla aos refugiados. Esse debate gira, frequentemente, em torno da adoção ou da crítica à denominada "abordagem dos direitos humanos". Tal perspectiva implica interpretar e aplicar os diversos elementos da definição de refugiado - para o reconhecimento desse status a um indivíduo - dentro do contexto dos padrões internacionais de direitos humanos (FOSTER, 2007). A discussão travada ao redor dessa abordagem concerne, sobretudo, a um aspecto controverso da definição: o significado de "perseguição".

A Convenção de 1951 não define o que entende por "perseguição", apenas afirmando ser o refugiado a pessoa que "temendo ser perseguida" cruza uma fronteira internacional (ONU, 1951). Feller sustenta que não existir, na Convenção, uma definição do termo "perseguição" é indicativo do fato de que suas formas são variadas. Diante da ausência de explicitação na definição, a determinação se há ou não perseguição geralmente é feita em referência aos direitos da pessoa que estão sendo violados (FELLER, 2001). A afirmação de Feller reflete a não-existência, na literatura, de uma interpretação consensual do termo. De fato, o significado de "perseguição" representa ampla discordância entre os autores e os tomadores de decisão (decision-markers). Já em 1979, o ACNUR tentou resolver tal embate

\footnotetext{
${ }^{4}$ Além dos autores aqui apresentados, outros destacam essa relação, como Malkki (1995), Bhaba (1996) e Goodwin-Gill (2001).
} 
apresentando uma interpretação para o termo ${ }^{5}$, sustentando que a partir do artigo $33^{\circ}$ da Convenção é possível inferir que uma ameaça à vida ou liberdade devido a raça, religião, nacionalidade, opinião política ou pertencimento a grupo social é sempre perseguição. Ademais, outras sérias violações de direitos humanos pelas mesmas razões também podem constituir perseguição (UNHCR, 1992). Essa publicação do ACNUR, contudo, não encerrou a controvérsia, vide as discussões que a sucederam e que ainda hoje se desdobram na literatura.

Foster (2007) identifica como um dos desenvolvimentos mais recentes na jurisprudência do Direito dos Refugiados o movimento em direção a um entendimento dos componentes da definição de refugiado pautado no contexto dos padrões internacionais dos direitos humanos, ou seja, ressalta como desenvolvimento importante do DIR a adoção, pelos tomadores de decisão, da "abordagem dos direitos humanos". Segundo essa autora, tal interpretação já foi defendida por Vernant, em 1953, quando este sugeriu que perseguição devia ser equacionada a "sanções e medidas severas de natureza arbitrária, incompatíveis com os princípios colocados pela DUDH"; mas sua ampla aceitação resulta da análise inovadora produzida por Hathaway em 1991. Segundo esse autor, baseando-se nos propósitos da Convenção, "perseguição" pode ser definido como "a violação prolongada e sistemática de direitos humanos básicos demonstrativa da falha de proteção do Estado" (HATHAWAY, 1991, p. 104-105).

Para Hathaway (1991), a Carta de Direitos Humanos (composta pela DUDH, o Pacto Internacional de Direitos Civis e Políticos - PIDCP - e o Pacto Internacional de Direitos Econômicos, Sociais e Culturais - PIDESC), em razão do consenso que representa sobre o entendimento do dever mínimo devido pelo Estado a seus nacionais, deve conformar o entendimento sobre a existência de perseguição em um determinado caso. Logo, o DIR deve tratar de ações que negam a dignidade humana de forma significativa; e, para tal, a negação prolongada e sistemática de direitos humanos fundamentais é o padrão apropriado. (HATHAWAY, 1991). De acordo com a Carta de Direitos Humanos, Hathaway (1991) identifica quatro tipos distintos de obrigações estatais frente a seus cidadãos, a partir dos quais é possível avaliar a existência de perseguição.

Primeiramente, destacam-se os direitos cuja derrogação não é permitida em caso algum, mesmo em caso de emergência nacional (conforme artigo $4^{\circ}$ do PIDCP) - direito contra privação arbitrária da vida; proteção contra tratamento ou punição cruel, desumana ou

\footnotetext{
${ }^{5}$ No "Manual sobre procedimentos e critérios para determinação do status de refugiado", reeditado em 1992.
} 
degradante; liberdade em relação à escravidão; proibição de prossecução por atos cometidos anteriormente à legislação referente; direito de reconhecimento de personalidade jurídica e liberdade de pensamento, consciência e religião. A falha em se assegurar tais direitos sob quaisquer circunstâncias equivaleria, segundo Hathaway (1991), a perseguição.

Em seguida, Hathaway trata dos direitos possíveis de derrogação durante uma emergência pública que ameaça a vida da nação e que seja oficialmente proclamada (conforme artigo $4^{\circ}$ do PIDCP) - liberdade contra detenção ou prisão arbitrária; direito de igualdade de proteção; direito, em procedimentos criminais, a audiência pública e justa e de presunção de inocência até provada a culpa; proteção da privacidade e integridade pessoal e familiar; direito à movimentação interna e escolha de residência; liberdade para deixar e retornar a seu próprio país; liberdade de opinião, expressão, assembleia e associação; direito de formar e integrar sindicatos; direito a participação no governo, acesso a emprego público sem discriminação e voto em eleições genuínas e periódicas. A falha em se garantir quaisquer desses direitos constituirá uma violação do dever básico de proteção do Estado, a menos que se demonstre que a derrogação foi derivada de exigências de uma situação real de emergência, que a mesma não é inconsistente com outros aspectos do direito internacional e que não foi aplicada de forma discriminatória.

O terceiro grupo de direitos não impõe padrões de realização absolutos e imediatamente vinculantes, mas requer que os Estados tomem atitudes para realizá-los progressivamente ao máximo de seus recursos disponíveis, de forma não-discriminatória direito ao trabalho, inclusive a condições justas e favoráveis de emprego, remuneração e descanso; direito a alimentação, vestuário, moradia, cuidados médicos; segurança social; educação básica; proteção da família e liberdade para se engajar e se beneficiar de expressão cultural, científica, literária e artística. Em relação a esses direitos, um Estado não cumpre suas obrigações quando os ignora, conquanto sua capacidade fiscal para assegurá-los, ou exclui uma minoria da população de seu usufruto.

Por fim, o quarto grupo refere-se àqueles direitos reconhecidos na DUDH, mas não codificados em nenhum instrumento vinculante e que estão, assim, fora do escopo de dever básico de proteção do Estado, como o direito de ter e não ser arbitrariamente privado de propriedade e o direito de ser protegido contra o desemprego. Hathaway (1991) propõe, assim, um método para averiguação da existência de perseguição baseado na Carta de Direitos e fundamentado nas obrigações de proteção do Estado em relação a seus cidadãos. A falha em 
se assegurar determinados direitos sob determinadas circunstâncias e de determinadas formas representa, logo, uma falha da proteção estatal, equivalendo a perseguição e justificando a proteção internacional.

Para Foster (2007), a abordagem desenvolvida por Hathaway é essencial para a capacidade de se interpretar a Convenção de 1951 de forma progressiva, para abarcar demandas envolvendo, por exemplo, a perseguição baseada em gênero. Revela-se especialmente relevante para a argumentação da própria Foster, que trabalha com a tese de que a inclusão de direitos socioeconômicos na DUDH e no PIDESC provê autoridade persuasiva para a visão de que as violações de direitos socioeconômicos podem equivaler a perseguição. A argumentação de Foster baseia-se na premissa de que o DIDH é uma referência apropriada para se interpretar vários aspectos da definição de refugiado, estando, portanto, inclusa na denominada "abordagem dos direitos humanos".

Foster (2007) aponta aspectos importantes da relação entre direitos humanos e refúgio. Em primeiro lugar, sustenta a autora que a referência à DUDH no preâmbulo da Convenção de 1951 leva à interpretação de que o objetivo da Convenção é fundamentalmente buscar um propósito inspirado nos direitos humanos - especificamente, prover proteção internacional àqueles indivíduos que se encaixam na definição de refugiado. Outra questão evidenciada é a finalidade do documento, predominantemente relacionada a direitos humanos: os artigos $2^{\circ}$ a $34^{\circ}$ concernem à clarificação dos direitos conferidos àqueles indivíduos reconhecidos como refugiados. Segundo Foster, o objetivo principal da Convenção não foi definir quem é um refugiado, mas dispor os direitos derivados desse reconhecimento. Assim, a Convenção proveria reparação para certas violações de direitos humanos, dando a esses indivíduos a oportunidade de viver com maior liberdade e dignidade que em seu país de origem.

Foster conclui, a partir da análise empreendida em seu livro, que a Convenção de 1951 é capaz de abarcar um conjunto de reivindicações que se pensava estarem fora do escopo desse tratado. Esta conclusão não se baseia somente em possibilidade teórica, mas é sustentada por uma jurisprudência nascente que tem demonstrado serem os tomadores de decisão capazes e dispostos a transcenderem rótulos considerados simplistas como "migrante econômico" e "migrante voluntário". A abordagem da autora não levanta a questão sobre defasagem ou necessidade de revisão da Convenção, tratando basicamente de como a Convenção, o mais importante instrumento internacional para a questão dos refugiados, pode ser interpretada e implementada de forma que reflita os entendimentos contemporâneos do 
escopo da proteção dos direitos humanos. Dessa forma, não questiona os elementos definidores do instituto. Sustenta que o dano sofrido tem que ser suficientemente sério para equivaler a perseguição - isto é, que há a necessidade de apontar uma violação essencial de direitos socioeconômicos que envolva a falha do Estado em assegurar a provisão nãodiscriminatória de direitos básicos - e há a necessidade de se vincular o dano sofrido a um dos motivos elencados pela Convenção.

A perspectiva de Aleinikoff (1991) também pode ser incluída no rol da "abordagem dos direitos humanos", embora se distinga porque não somente equipara perseguição a violação de direitos humanos, mas demonstra outra percepção sobre os cinco motivos da Convenção. Esse autor afirma que o foco da Convenção é o próprio significado de perseguição, um entendimento comum que requer que o dano em questão seja de natureza grave. Aleinikoff nota que uma revisão dos trabalhos preparatórios da Convenção demonstra que não houve ênfase - durante a discussão - nos tipos de perseguição que qualificariam um indivíduo como refugiado. Assim, o autor sustenta que a Convenção foi escrita tendo como intenção proteger todas as pessoas existentes na Europa que tinham sido ou provavelmente seriam vítimas de perseguição. Segundo ele, nenhuma forma de perseguição foi intencionalmente excluída, embora várias outras exclusões tenham sido escritas na Convenção (ALEINIKOFF, 1991). Dessa forma, a história da Convenção não provê sustentação para uma leitura limitada dos motivos que caracterizam perseguição; ao contrário, demonstra um propósito de escrever uma definição de refugiado ampla o suficiente para cobrir as então existentes vítimas de perseguição. Para Aleinikoff, duas observações apóiam sua análise. Primeiro, a categoria "membro de grupo social" parece ter sido adicionada com nenhum outro motivo que não suprir uma possível lacuna derivada das outras, mais específicas, categorias. Em segundo lugar, no Manual do $\mathrm{ACNUR}^{6}$, a utilização dos cinco motivos para explicar "perseguição" indica, apenas, o aspecto injustificado e intolerável da inflição do dano. Assim, enquanto a existência de um dos cinco motivos pode sinalizar o aspecto qualitativo da definição de perseguição, não está de forma alguma claro que a perseguição deve ser restringida aos mesmos ou que um solicitante deve ser capaz de demonstrar conclusivamente que um dos cinco motivos existe para estabelecer a perseguição (ALEINIKOFF, 1991).

A análise de Aleinikoff implica, portanto, averiguar a existência de perseguição segundo o dano causado e não conforme o motivo que leva a esse dano - estabelece-se como

\footnotetext{
${ }^{6}$ Vide nota 5.
} 
foco a existência da perseguição, e não o motivo que leva à mesma. A questão, então, passa a ser decidir quais tipos de danos são tão severos que sua imposição constitui perseguição. Nesse sentido se invoca os direitos humanos: há perseguição quando se demonstra a existência de privação de direitos humanos fundamentais ou de dano sério imposto como penalidade ao exercício de um direito fundamental.

A argumentação de Gorlick (2000) também pode ser incluída no rol da "abordagem dos direitos humanos", pois defende que diversos instrumentos e mecanismos universais, regionais e domésticos de direitos humanos podem ser utilizados para aumentar a proteção dos refugiados e de solicitantes de refúgio. Embora não trate especificamente do significado de "perseguição", Gorlick manifesta-se, em algumas passagens do texto, favoravelmente a uma abordagem mais flexível e fundada na proteção (o propósito da Convenção) para interpretar a Convenção, inclusive o termo "perseguição". Nota, ainda, que, no que concerne ao foco desse documento em direitos humanos, há uma linha direta de descendência da Carta das Nações Unidas e da DUDH, afirmada no preâmbulo; e uma análise das provisões contidas nesse instrumento internacional o revela como uma extraordinária "Carta de Direitos" para os refugiados. Conquanto o conjunto impressivo de direitos que consta na Convenção, Gorlick sustenta que instrumentos internacionais de direitos humanos como o PIDCP e o PIDESC podem prover uma proteção legal ainda mais ampla aos refugiados.

No que se refere à discussão abarcada pelo nosso texto - concernente ao momento anterior à determinação do status de refugiado - Gorlick (2000) declara que o organismo mais ativo em desenvolver jurisprudência no interesse dos refugiados é o Comitê contra Tortura (estabelecido pela Convenção contra Tortura e outros Tratamentos ou Penas Cruéis, Desumanos ou Degradantes, 1984). Muitos solicitantes cujo status como refugiado não foi reconhecido têm recorrido a esse órgão para proteção alternativa contra expulsão e retorno ao país de origem. Esse mecanismo é particularmente importante em casos em que uma interpretação restritiva da definição de refugiado resultou em negação do reconhecimento dessa condição a indivíduos com necessidade de proteção internacional. De forma geral, afirma Gorlick (2000), os trabalhos desse comitê com questões envolvendo refugiados têm estabelecido um padrão maior de proteção.

Como afirmamos anteriormente, o debate sobre a relação entre direitos humanos e refúgio geralmente se desenvolve em torno da defesa da "abordagem dos direitos humanos" ou da crítica a mesma. Enquanto autores como Hathaway, Foster e Aleinikoff adotam tal 
perspectiva, alguns buscam desconstruir seus fundamentos. Uma dessas críticas é apresentada por Steinbock (1998). Segundo esse estudioso, os autores que defendem a perspectiva dos direitos humanos não provêm um ajuste adequado entre seus próprios propósitos e o texto da definição de refugiado. Na verdade, eles tentariam extrair um propósito da Convenção e, então, subordinariam a linguagem do texto ao propósito descoberto, um processo que encontra pouca sustentação nos métodos aceitos de interpretação estatutária e de tratados. Steinbock sustenta que, para tais argumentações, a questão relevante é se a violação de direitos humanos ocorre e se resulta em dano suficientemente sério que equivalha a perseguição. Isso significaria uma mudança do foco do Direito dos Refugiados das causas para os efeitos do dano. Tal interpretação deriva de sua leitura de que para esses autores a definição de refugiado protege contra violações de direitos humanos reconhecidos, independentemente se o dano é causado devido a um dos cinco motivos. Ele questiona, então, o porquê de não terem os redatores da Convenção especificado a intenção de cobrir a imposição de sérios danos na falta de um dos cinco motivos, caso fosse esse o propósito.

Embora entenda a Convenção de 1951 e o Protocolo de 1967 como instrumentos de direitos humanos, Steinbock (1998) sustenta que os padrões amplos de direitos humanos não devem ser utilizados diretamente para conformar o entendimento dos elementos da definição de refugiado. Mais especificamente, ele afirma que somente alguns direitos humanos podem ser entendidos como constituindo a estrutura para a interpretação da Convenção. Justificando esse entendimento, o autor destaca o fato de que a Convenção menciona vários dos direitos humanos que haviam sido recentemente enunciados na DUDH, mas não todo esse rol de direitos. Dessa forma, após analisar o texto, a história e o contexto da Convenção, Steinbock conclui que a definição de refugiado centra nos princípios de não-discriminação, condenação da culpa coletiva e proteção da liberdade de pensamento e expressão - servindo, portanto, os propósitos identificados, para proteger importantes direitos humanos, mas não sendo coextensivos ao completo conjunto de direitos humanos.

Por fim, outro ponto mencionado, porém pouco explorado, por Steinbock, refere-se ao impacto prático da "abordagem dos direitos humanos". Ele destaca - tomando como base o método proposto por Hathaway para verificação da existência de perseguição - que o amplo conjunto de direitos humanos, cuja violação corresponderia a perseguição tornaria milhões de pessoas refugiados em potencial. O autor afirma que uma descrição tão extensiva de perseguição ora revolucionaria o Direito Internacional dos Refugiados, ora demandaria 
seletividade entre refugiados potenciais baseada no tipo ou na qualidade do dano. Em qualquer um dos casos, o impacto prático seria enorme (STEINBOCK, 1998).

Em resposta a Steinbock (1998), Foster (2007) considera que o primeiro critica a "abordagem dos direitos humanos" a partir da noção equivocada de que a mesma simplesmente não considera os cinco motivos para a verificação de existência de perseguição. Foster afirma que essa abordagem não implica necessariamente que toda desconsideração aos direitos humanos automaticamente equivale a perseguição. Assim, o solicitante tem, sim, que satisfazer outros aspectos da definição, notadamente os cinco motivos que levam à perseguição. Embora a assertiva de Steinbock possa ser aplicada a Aleinikoff (1991) - o qual realmente sustenta que os cinco motivos são somente ilustrativos das razões que não justificam danos graves aos indivíduos -, a mesma realmente não encontra fundamento na análise de Hathaway (1991) - também utilizada como parâmetro para a crítica de Steinbock à "abordagem dos direitos humanos" -, pois esta não rechaça a consideração dos cincos motivos para verificação da existência de perseguição.

Foster (2007) também contrapõe a argumentação de Steinbock (1998) no que diz respeito a outra questão, apontando para a problemática denominada, por ela, de "abordagem de dicionário" (dictionary approach). Esta perspectiva é aquela que recorre ao dicionário para buscar o significado usual dos termos que compõem a definição de refugiado da Convenção, sem considerar, assim, o objeto e os objetivos do documento (FOSTER, 2007). Foster identifica o impacto prático ressaltado por Steinbock (1998) - como um empecilho à "abordagem dos direitos humanos" - como um "floodgate concern" (ALEINIKOFF, 1991; BHABHA, 1996), ou seja, uma preocupação vinculada à abertura de uma brecha (ou de uma comporta) para a entrada de (um grande número de) indivíduos que, do contrário, não seriam considerados refugiados. A crítica da autora não se relaciona à preocupação em si com o número possivelmente significativo de refugiados derivado do "novo" entendimento sobre perseguição, mas ao fato de que essa afirmação implica assumir que há um significado usual (ou de senso comum) de "perseguição", o que não procede; nesse sentido, a argumentação de Steinbock basear-se-ia em significados estritos oriundos do dicionário. Esta crítica, entretanto, não é sustentada quando se observa atentamente a obra de Steinbock, pois o mesmo afirma que uma abordagem exclusivamente textual da Convenção simplesmente não pode responder a muitas questões levantadas pelos solicitantes de asilo - incorrendo o risco de minar importantes preocupações normativas abarcadas pela definição de refugiado. Exatamente por 
esse motivo, ele recorre não somente ao texto, como ao contexto e à história da Convenção para inferir os propósitos desse instrumento internacional.

Embora a crítica de Foster (2007) à "abordagem de dicionário" - verificada pela autora em diversas cortes que determinam o status de refugiado no mundo - não seja adequada à argumentação de Steinbock (1998), devido às ressalvas elaboradas por esse autor, entendemos que a preocupação levantada concerne à limitação que uma tal perspectiva pode implicar para o conceito de refugiado. O entendimento do significado de "perseguição" baseando-se apenas em definições de dicionários - que ignoram o contexto em que o regime para os refugiados surgiu e seus objetivos - incorre o risco de criar "exceções anômalas" isto é, negar proteção a pessoas consideradas refugiadas de acordo com o espírito da Convenção - minando, assim, a estrutura de proteção aos refugiados (FELLER, 2001).

Interessantemente, o trabalho de Wilsher (2003) alude ao significado de dicionário, sustentando a inadequação da "abordagem dos direitos humanos", porém visando uma interpretação mais ampla do termo - e não a restringindo como acontece na maior parte dos casos em que se recorre a essa abordagem. Segundo esse estudioso, buscar o significado do termo "perseguição" no dicionário implica constatar que a definição de refugiado abarca os atores não-estatais como possíveis agentes da perseguição, não a limitando a resultado de ações do Estado, pois perseguir significa simplesmente "procurar com inimizade e maltrato",

Em seu texto, Wilsher questiona o grau de proteção suprida pela Convenção de 1951 a vítimas de perseguição realizada por atores não-estatais. É amparado por esse debate que o autor rejeita a "abordagem dos direitos humanos". Basicamente, sua argumentação direcionase a contrapor a afirmação de Hathaway (1991) - de que "perseguição equivale a uma negação prolongada e sistemática de direitos humanos fundamentais”. Wilsher sustenta que compreender "perseguição" enquanto negação de direitos humanos implica uma dificuldade real para a determinação do status de refugiado quando o perpetrador do dano é um agente não-estatal. Conforme sua argumentação, em Direito Internacional, o Estado é o único ator que detém o dever que caracteriza a contraparte dos direitos humanos - o dever de proteção -, isto é, as obrigações em termos de direitos humanos são atribuídas ao Estado. Nesse sentido, infere-se que um ator não-estatal não pode, de modo estrito, infringir direitos humanos; somente o Estado pode fazê-lo. Assim, uma formulação do entendimento de "perseguição" baseada somente em direitos humanos pode ser imprópria no contexto de atores não-estatais

\footnotetext{
7 Tradução livre de "pursue with enmity and ill-treatment" (WILSHER, 2003, p. 80-81).
} 
(WILSHER, 2003). Por esse motivo, Wilsher assevera que perseguição deve ser entendida como a imposição de dano sério e prolongado sobre a vítima, de modo a interferir em qualquer aspecto central da dignidade humana.

Na perspectiva do autor, uma interferência de atores não-estatais com interesses que impactam questões protegidas por instrumentos de direitos humanos pode constituir perseguição. Dessa forma, os direitos humanos são evidentemente relevantes para a perseguição, porém, não devem defini-la - no sentido de requerer uma responsabilidade estatal como condição sem a qual a perseguição não existe. Portanto, Wilsher (2003) contrapõe-se à "abordagem dos direitos humanos" por afirmar que a mesma restringe o escopo da Convenção ao não incluir vítimas de perseguição realizada por atores não-estatais.

O mesmo argumento da subinclusividade é apontado por Edwards (2003) como fundamento para sua rejeição à “abordagem dos direitos humanos”. Nessa obra, a autora visa apontar a necessidade de sensibilidade a questões de gênero e de idade nas políticas e práticas para os refugiados; sendo esse um importante passo para a aplicação não-discriminatória do Direito dos Refugiados. Edwards ressalta o fato de que o Preâmbulo da Convenção de 1951 convoca os Estados a assegurarem aos refugiados o mais amplo exercício de seus direitos e liberdades fundamentais, o que implica uma análise do DIR dentro de um contexto humanitário e de direitos humanos mais amplo. Também afirma que a Convenção é um instrumento de direitos humanos que trata de formas contemporâneas de violações a esses. Contudo, argumenta que, embora a perseguição geralmente envolva rupturas do Direito Internacional dos Direitos Humanos, não é necessário em cada caso identificar uma violação desses direitos para identificar a existência de perseguição.

Edwards nota que não há uma definição internacionalmente aceita do que constitui perseguição e, por esse motivo, seria imprudente limitar sua pertinência a, apenas, sérios abusos de direitos humanos. Destaca-se a possibilidade de que nem todas as formas de perseguição tenham sido identificadas ou codificadas no Direito Internacional dos Direitos Humanos, de modo que a equivalência estrita de perseguição à violação de direitos humanos possibilita o não-reconhecimento como refugiadas de vítimas às quais tal admissão seria pertinente de acordo com os propósitos da Convenção. A proteção disponível sob o Direito dos Refugiados, assim, não deve ser restringida pelo estrito alinhamento ao DIDH (EDWARDS, 2003). 
O que observamos na literatura é que a maior parte dos autores, ao contraporem-se à "abordagem dos direitos humanos", foca questões específicas, como a subinclusividade ou a impossibilidade prática. A perspectiva de Nathwani (2003) destaca-se, nesse contexto, por desenvolver uma argumentação que visa desconstruir essa abordagem em diferentes aspectos. Seu trabalho busca encontrar um princípio que possibilite superar uma política severa de controle de imigração que afete, de maneira negativa, a proteção aos refugiados. O autor parte, no que concerne aos direitos humanos, do frequente argumento de que o Direito Internacional dos Refugiados pode ser visto como um sistema subsidiário para a proteção dos direitos humanos - abordagem (que tem como um de seus maiores defensores James Hathaway) que entende a perseguição como uma violação de direitos humanos.

A primeira questão discutida por Nathwani diz respeito à frequente assertiva de que a referência, no Preâmbulo da Convenção, à Carta das Nações Unidas e à DUDH comprova o entendimento de que o DIR é um sistema subsidiário da proteção aos direitos humanos. Para Nathwani, inferir essa subsidiaridade significa entender que àqueles indivíduos cujos direitos humanos não foram assegurados em seu país é garantida a proteção em outro território por meio do Direito Internacional dos Refugiados, o que, por conseguinte, implica dizer que esta vertente do Direito Internacional somente se torna operativa quando uma violação de direitos humanos ocorre - ou seja, equivale-se perseguição à violação de direitos humanos. Segundo o autor, de fato, um olhar atento ao preâmbulo somente revela que o propósito da Convenção é assegurar aos refugiados o usufruto de seus direitos e liberdades fundamentais no país de asilo - isto é, a Convenção reafirma o princípio de que os direitos humanos abarcam todos os indivíduos, e não que a violação de direitos humanos é a condição para o status de refugiado. Assim, o texto do preâmbulo não forneceria um argumento forte para a afirmação de que o DIR tem como premissa o Direito Internacional dos Direitos Humanos (NATHWANI, 2003).

Outra questão ressaltada por Nathwani concerne à distorção do reconhecimento do status de refugiado que a visão desses indivíduos como vítimas de violação de direitos humanos implicaria. O conceito de refugiado como aquele cujos direitos humanos foram violados gera uma acusação ao Estado de origem. Nathwani nota que o preâmbulo da Convenção expressa o desejo de que o problema dos refugiados não se torne causa de tensão entre os Estados. Para Nathwani, a teoria da perseguição como violação de direitos leva especificamente a esta consequência. Isso implica conter o reconhecimento do status de refugiado uma crítica implícita ao Estado de origem. Toda essa abordagem, portanto, submeteria os refugiados à política internacional. Como a função principal do Direito 
Internacional dos Refugiados é prover espaço seguro para esses indivíduos - a qual somente pode ser desempenhada caso seja neutro -, a "abordagem dos direitos humanos" para a proteção dos refugiados provavelmente levaria à não-realização desse objetivo.

Outro ponto levantado por Nathwani sobre a "abordagem dos direitos humanos" concerne à política de imigração dos países - questão ao redor da qual gira toda a argumentação de seu livro. $\mathrm{O}$ autor sustenta que se todas as violações de direitos humanos levarem ao reconhecimento do status de refugiado, os Estados ricos do Ocidente não poderão exercer sua política restritiva de imigração, o que geraria a necessidade de se enfatizar algumas violações de direitos em detrimento de outras. Considerando a proclamada unidade e interdependência do DIDH, tal hierarquização - somente baseada nos direitos humanos - não se revela possível, de modo que esse constitui outro aspecto que torna inadequada a "abordagem dos direitos humanos" para a proteção dos refugiados.

A dificuldade de hierarquização e a falta de motivação dos Estados constituem, para Nathwani, os dois maiores desafios para a "abordagem dos direitos humanos". Quanto ao último aspecto - a falta de motivação - esse autor afirma que ao enfatizar os direitos humanos, os autores não consideram o auto-interesse como força motivadora dos Estados. Como não se pode sustentar que os Estados servem ao seu auto-interesse ao protegerem refugiados de violações de direitos humanos ocorridas em outros territórios, a ênfase nos direitos humanos foca demasiadamente no altruísmo dos Estados. E parece ser exatamente por ter sido atingido o limite do altruísmo que há uma crise da proteção aos refugiados (NATHWANI, 2003).

Por fim, frente às limitações - por ele identificadas - não superadas pela "abordagem dos direitos humanos", assim como às de outras argumentações que buscam identificar uma razão que justifique a proteção aos refugiados em um contexto de severa política de imigração, Nathwani (2003) apóia-se no princípio da "necessidade" como aquele capaz de criar uma exceção dentro desse contexto político de restrição à mobilidade humana. Embora possa haver uma sobreposição entre direitos humanos e "necessidade" - já que a necessidade frequentemente resulta de violações de direitos humanos -, nem sempre as violações de direitos humanos criam o perigo imediato e intenso associado ao conceito de necessidade. 


\section{A relação orgânica}

Como afirmado anteriormente, o refúgio pode ser caracterizado por dois momentos: o anterior à determinação do status de refugiado e o posterior a tal reconhecimento. Esse artigo busca demonstrar a impossibilidade de desvinculação entre a concepção contemporânea da proteção internacional aos refugiados e a afirmação e garantia dos direitos humanos limitando a análise ao momento anterior ao reconhecimento do status de refugiado, aquele referente aos aspectos que coagem à fuga e que legitimam a admissão como refugiado por outro país. Para isso, traçamos uma revisão bibliográfica sobre como os autores têm tratado essa relação, principalmente no que concerne ao vínculo entre violação de direitos humanos e o significado do termo "perseguição" da definição de refugiado.

A análise empreendida aponta para algumas conclusões já bastante destacadas na literatura sobre refúgio e sobre direitos humanos. A primeira refere-se ao fato de que há uma aproximação histórica entre o regime internacional dos refugiados que vige na atualidade e o regime dos direitos humanos. Ambos mecanismos são resultados de arranjos anteriores que estabeleceram, parcialmente, as bases - principiológicas ou institucionais - as quais foram tomadas como referência para suas atuais configurações. No caso dos direitos humanos, Comparato (2010) ressalta que após a II Guerra Mundial houve o aprofundamento e a definitiva internacionalização dos direitos humanos, um segundo momento da afirmação histórica internacional de direitos iniciada na segunda metade do século XIX. No tocante ao regime para os refugiados, esse tem como precedente o arranjo internacional formulado na década de 1920, tendo estabelecido no pós-guerra uma base mais institucionalizada para a cooperação internacional (BETTS; LOESCHER, 2011).

A segunda constatação diz respeito ao fato de que a similaridade histórica, de fato, decorre da identificação filosófica existente entre os dois regimes. Tanto o regime dos direitos humanos quanto o dos refugiados visam à proteção do indivíduo, ou seja, à garantia de direitos e liberdades básicos que têm como parâmetro a dignidade da pessoa. Ambos foram delineados em um momento no qual a necessidade de proteção desses direitos estava em evidência: os acontecimentos ocorridos durante a II Guerra Mundial apontaram o imperativo de se estabelecer garantias para que situações de amplo desrespeito à dignidade da pessoa não voltassem a se repetir - o que resultou no regime internacional de direitos humanos - ou que, caso se repetissem, houvesse uma possibilidade para que as vítimas escapassem de tal situação de desrespeito - tendo sido configurado o regime contemporâneo dos refugiados. 
Contudo, o que se explora pouco na literatura e que é o cerne para superar a discussão sobre se os termos da definição devem ou não ser interpretados conforme os padrões internacionais de direitos humanos é o fato de que as duas questões não são apenas histórica e filosoficamente vinculadas, mas também organicamente, no sentido de que o conceito atual de refúgio e os padrões de direitos humanos não somente se consolidaram em períodos históricos similares e têm como objetivo análogo a proteção da pessoa humana: de fato, a própria ideia de refúgio consolidada na atualidade é fundamentada na ideia de direitos humanos ${ }^{8}$.

Algumas questões apontadas pelos autores analisados ressaltam essa dimensão da relação entre direitos humanos e refúgio. A primeira está contida na referência frequente dos autores ao direito de asilo. Lembremos que a Declaração Universal dos Direitos Humanos estabeleceu em seu artigo $14^{\circ}$ que "Todo ser humano, vítima de perseguição, tem o direito de procurar e gozar asilo em outros países." (ONU, 1948). É interessante notar que a questãochave para invocação do direito de buscar e gozar de asilo em outros países, segundo essa declaração, é a perseguição - também o elemento central da definição de refugiado contida na Convenção de 1951. Nesse sentido, é possível afirmar que a Convenção de 1951 veio estabelecer os parâmetros para que esse direito reconhecido na DUDH pudesse ser garantido.

Outros pontos contidos na DUDH também corroboram o argumento de que a ideia de proteção internacional da pessoa se funda no reconhecimento internacional de direitos humanos. Primeiro, conforme o artigo $2^{\circ}$ da DUDH,

1. Todo ser humano tem capacidade para gozar os direitos e as liberdades estabelecidos nesta Declaração, sem distinção de qualquer espécie, seja de raça, cor, sexo, idioma, religião, opinião política ou de outra natureza, origem nacional ou social, riqueza, nascimento, ou qualquer outra condição. (ONU, 1948, grifo nosso).

A afirmação de que todos os indivíduos devem gozar das garantias que estipula, sem que nenhuma distinção seja feita, tem uma relação direta com a justificativa para a existência do instituto do refúgio. É necessário ressaltar que, segundo a Convenção de 1951, é refugiado aquela pessoa que ao sofrer (ou temer) perseguição devido a raça, religião, nacionalidade, opinião política ou pertencimento a grupo social, procurou proteção deixando seu país de origem ou residência habitual. Dessa forma, observamos que é a violação do supracitado artigo 2 da Declaração Universal - representada por uma discriminação materializada em

\footnotetext{
${ }^{8}$ O regime internacional dos refugiados contemporâneo tem como precedentes os arranjos internacionais formulados a partir da década de 1920 para trato da problemática, sob auspício da Liga das Nações. Todavia, inicialmente tais mecanismos não demonstravam aproximação com a ideia de direitos humanos - então ainda em processo inicial de internacionalização. Tal questão será discutida mais adiante no texto.
} 
forma de perseguição - que leva à invocação do direito de reconhecimento da condição de refugiado. Assim, o indivíduo é reconhecido enquanto refugiado porque, em relação a ele, foi desconsiderado o fato de que todo ser humano deve gozar de direitos e liberdades sem distinção alguma.

A DUDH também afirma que

Considerando que o desprezo e o desrespeito pelos direitos humanos resultaram em
atos bárbaros que ultrajaram a consciência da Humanidade e que o advento de um
mundo em que os homens gozem de liberdade de palavra, de crença e da liberdade
de viverem a salvo do temor e da necessidade foi proclamado como a mais alta
aspiração do ser humano comum,
[...]
Considerando que os Estados-Membros se comprometeram a promover, em
cooperação com as Nações Unidas, o respeito universal aos direitos e liberdades
humanas fundamentais e a observância desses direitos e liberdades, [...] (ONU,
1948, grifo nosso).

Esses dois excertos demonstram que, ao assinarem a Declaração, os países se comprometeram a, por meio da cooperação internacional, assegurar um mundo em que todos gozem de liberdade de palavra, de crença e da liberdade para viverem longe do temor e da necessidade. Essa é, sem dúvida, a razão maior da adoção de um instrumento internacional de proteção à pessoa - a Convenção de 1951 - que, por meio de uma concertação internacional, visa que a proteção à pessoa e a garantia de seus direitos se dêem não obstante a falha do Estado de origem em prover tal proteção.

Outro ponto de reflexão - evidenciado por alguns autores - é a referência na própria Convenção à DUDH: “Considerando que a Carta das Nações Unidas e a Declaração Universal dos Direitos Humanos, aprovada em 10 de dezembro de 1948 pela Assembleia Geral, afirmaram o princípio de que os seres humanos, sem distinção, devem gozar dos direitos do homem e das liberdades fundamentais [...]" (ONU, 1948). Isso significa dizer que 1) um fundamento por trás da Convenção é a não-discriminação para o usufruto pelos indivíduos de direitos e liberdades fundamentais; 2) a Carta das Nações Unidas e a Declaração Universal são os documentos que balizam esses direitos e liberdades que fundamentam a elaboração e adoção da Convenção.

É importante, ainda, considerar os antecedentes históricos da Convenção de 1951. Como já afirmamos, esse documento tem como base os arranjos formulados desde a década de 1920 para o trato da problemática relacionada aos refugiados. Um aspecto que se destaca é o fato de que na primeira convenção elaborada sobre o estatuto do refugiado, em 1933, embora houvessem sido enumerados alguns (poucos) direitos referentes à condição de 
refugiado, a preocupação primordial disse respeito ao status jurídico desses indivíduos no país de asilo. Mesmo o princípio do non-refoulement ${ }^{9}-$ atualmente clamado como cerne da proteção ao refugiado - não parece ser relacionado, naquele momento, a um direito do indivíduo; tendo sido incluído no capítulo sobre medidas administrativas. O mesmo pode ser afirmado no que concerne à Convenção de 1938 sobre o Estatuto dos Refugiados Provenientes da Alemanha. Assim, o propósito primordial relacionado a direitos humanos somente se mostrou ser o alicerce da proteção internacional aos refugiados com a elaboração da Convenção de 1951 - fato que ressalta novamente o fundamento de direitos humanos imbricado na atual concepção de proteção internacional da pessoa humana.

Dessa forma, é possível sustentar que uma análise do texto, da história e do contexto da Convenção demonstra que o Direito Internacional dos Refugiados não é somente histórico e filosoficamente coincidente ao Direito internacional dos Direitos Humanos, mas, de fato, se funda nas ideias de direitos humanos. Foi a partir do reconhecimento no plano internacional de direitos e liberdades fundamentais - cuja garantia é necessária para a concretização da noção de dignidade da pessoa humana - que se tornou possível a configuração do atual regime internacional dos refugiados, que tem como alicerce a proteção (não meramente jurídica) desses indivíduos.

O DIDH reconheceu o princípio da não-discriminação e também que a soberania estatal não pode representar justificativa para o desrespeito à dignidade dos cidadãos. Baseada nesses princípios, a comunidade internacional acordou a necessidade de proteger o indivíduo quando seu Estado de origem é incapaz ou indisposto a cumprir com seu dever de proteção. Nesse sentido se caracteriza a relação orgânica evidenciada por esse trabalho. O Direito Internacional dos Refugiados - em sua configuração e aplicação atual - foi formulado com base nos princípios reconhecidos pelo DIDH, de modo que se tais princípios são desconsiderados, não é possível referir-se à atual concepção de proteção internacional da pessoa - objetivo do atual regime para os refugiados. Tal entendimento leva à superação da discussão sobre se os padrões internacionais de direitos humanos devem balizar a interpretação dos termos componentes da definição de refugiado. Uma vez sustentado que a proteção internacional se funda nos princípios dos direitos humanos - os quais uma vez desconsiderados anulam o fundamento dessa proteção -, torna-se evidente não apenas a

\footnotetext{
9 Princípio da não-devolução, segundo o qual um Estado Contratante não poderá expulsar ou rechaçar um refugiado para as fronteiras dos territórios em que sua vida ou liberdade seja ameaçada em decorrência de raça, religião, nacionalidade, grupo social ou opinião política (ONU, 1951).
} 
possibilidade, como a necessidade de que tais princípios constituam a referência para a interpretação, na contemporaneidade, dos instrumentos internacionais sobre refugiados. É possível, por conseguinte, sugerir que o instituto do refúgio busca reparar uma situação de violação de direitos humanos para garantir que o indivíduo - conforme consta na DUDH goze de liberdade de palavra, de crença e que esteja a salvo do temor da perseguição. Nesse sentido, podemos sustentar que o reconhecimento como refugiado visa corrigir uma situação específica de violação de direitos humanos: aquela materializada em forma de perseguição. Isso não significa afirmar que toda violação de direitos humanos equivale a perseguição, pois outros elementos da definição devem ser considerados para que se caracterize a condição de refugiado, notadamente o caráter discriminatório da inflição do dano - o qual se baseia em considerações de raça, religião, nacionalidade, opinião política ou grupo social - e o cruzamento de fronteiras internacionais. Porém, argumentar a favor de um entendimento do significado de perseguição vinculado à violação de direitos humanos é, sem dúvida, admitir o fundamento desse instituto nos direitos humanos e, assim, defender um processo de determinação do status de refugiado que esteja de acordo com os propósitos do regime internacional formulado para a proteção da pessoa.

\section{Reafirmando a "abordagem dos direitos humanos"}

Considerando nossa abordagem sobre a relação entre direitos humanos e refúgio, é possível desconstruir algumas das argumentações contra a "abordagem dos direitos humanos". A perspectiva de Edwards (2003) contra a essa abordagem refere-se ao fato de que é possível que nem todas as formas de perseguição tenham sido identificadas ou codificadas no DIDH, de forma que interpretar perseguição como estritamente violação de direitos humanos gera a possibilidade que vítimas de perseguição não prevista no DIDH não sejam reconhecidas como refugiados, limitando assim o alcance da Convenção de 1951 e agindo contra seus propósitos amplos de proteção. Embora em alguma medida essa crítica seja pertinente, por outro lado ela rechaça a "abordagem dos direitos humanos" por excesso de cautela e ignora a capacidade de adaptação do regime contemporâneo dos refugiados. Ao longo dos anos, os instrumentos internacionais para os refugiados vêm sendo alterados; não materialmente - pois a redação de tais instrumentos não foi alterada -, mas no que toca à sua interpretação. O entendimento sobre o significado dos termos da definiçãa vem modificandose - lado a lado com as novas compreensões sobre direitos humanos -, de modo a abarcar 
novas formas de perseguição, como, a perseguição devido à orientação sexual ou baseada em gênero. Na verdade, entender o propósito de direitos humanos imbricado na Convenção, ao conformar a compreensão de seus termos segundo padrões internacionais de direitos humanos, ao contrário do que afirmado por Edwards (2003), possibilita um maior espaço para adaptação de seu entendimento do que restringe esta possibilidade. Vale ressaltar que a autora em momento algum explicita sua compreensão sobre o termo "perseguição", porém, quando se refere à questão deixa implícita considerações fundadas na ideia de direitos humanos.

Wilsher (2003), por sua vez, posiciona-se contra a "abordagem dos direitos humanos" por acreditar que a mesma obsta a verificação de perseguição quando a mesma é realizada por atores não-estatais, já que a contraparte dos direitos humanos, ou seja, o imperativo de proteção, se assenta no Estado. Entretanto, esse autor não atenta o fato de que a definição afirma ser refugiado aquela pessoa que não pode ou não quer valer-se da proteção do Estado. Ou seja, embora os direitos humanos demandem uma contraparte de atuação do Estado, não significa que a violação de direitos humanos acontece somente quando este é o perpetrador da violação, mas também quando o mesmo não é capaz ou não está disposto a evitar ou corrigir tal situação de violação - o que caracteriza, após o cruzamento de fronteira internacional, a condição de refugiado. Dessa forma, em situações nas quais atores não-estatais agem impactando direitos e liberdades fundamentais que integram a ideia de direitos humanos há violação desses direitos, e o componente de responsabilidade estatal é identificável não por realizar, propriamente, o abuso, mas por não garantir que tais direitos não sejam violados.

Ademais, Wilsher (2003), tentando evitar o perigo de se negar proteção a refugiados perseguidos por atores não-estatais, propõe que a perseguição seja entendida como a imposição de dano sério e prolongado sobre a vítima de modo a interferir em qualquer aspecto central da dignidade humana. É possível crer, contudo, que os aspectos reconhecidos - até o momento - como centrais à dignidade humana já tenham sido traduzidos em termos de direitos humanos. Desse modo, resolvido o impasse interpretativo sobre como se atribuir responsabilidade estatal em caso de perseguição por agentes não-estatais, sua abordagem coincide com a dos direitos humanos.

A questão central da argumentação de Steinbock (1998) relaciona-se à impossibilidade de se equacionar perseguição a violação de direitos humanos porque uma análise do texto, contexto e história da Convenção revela que a definição de refugiado serve para proteger pessoas contra três formas relacionadas de dano: a perseguição da diferença, a atribuição de 
culpa coletiva e a punição pelo exercício de direitos de liberdade de expressão e crença. Por esse motivo, perseguição deve ser entendida somente de acordo com tais princípios. Steinbock infere esses princípios, como aqueles que regem a definição clássica de refugiado, por serem em torno desses direitos que giram as disposições da Convenção. Ele busca uma abordagem que se distinga da "abordagem dos direitos humanos" para evitar, assim as críticas direcionadas a tal perspectiva e conferir maior sustentação teórica à sua. Todavia, esse autor falha em demonstrar em quais aspectos sua própria abordagem difere daquela dos direitos humanos. Considerando que a maior parte dos autores da "abordagem dos direitos humanos" não abandona a necessidade da vinculação a um dos cinco motivos - o que caracteriza a perseguição pela diferença ressaltada por Steinbock -; que a condenação da culpa coletiva está implícita no Direito Internacional dos Direitos Humanos, como o próprio Steinbock ressalva; e que expressão e crença são dois direitos humanos internacionalmente consagrados, não fica clara a distinção que o autor busca traçar.

Somente em um ponto Steinbock (1998) demonstra a diferença de sua perspectiva para a dos direitos humanos. Isso acontece quando o autor destaca um tipo de perseguição o qual sua argumentação não pode sustentar como gerador da necessidade do reconhecimento da condição de refugiado; embora, ele o entenda como um caso que legitima a demanda por proteção internacional. O exemplo dado alude à execução sumária de palestinos que transgrediram a proibição da Autoridade Palestina de vender terras a judeus ${ }^{10}$. Na verdade, esses indivíduos foram perseguidos por uma atitude sua contrária à lei estabelecida no país. Porque os propósitos identificados por Steinbock como aqueles que fundamentam a Convenção centram na perseguição "pelo que se é, e não pelo que se fez", ele ressalta a incapacidade de sua argumentação de incluir tais pessoas na categoria de refugiados. Por outro lado, a "abordagem dos direitos humanos", por ser mais inclusiva, conseguiria tratar melhor da questão. No entanto, uma vez que essas são perseguidas por terem agido em desacordo a uma política que caracteriza a perseguição pela diferença, sua própria argumentação seria capaz de defender o status de refugiado desses indivíduos - já que a Convenção, segundo sua análise, gira em torno, entre outros princípios, da proteção contra a perseguição pela diferença e a ação estatal de perseguição direcionada a esses indivíduos, nesse caso, objetiva a perpetuação da perseguição de terceiros baseada na diferença. Uma vez englobado esses indivíduos na categoria de refugiados, a interpretação de Steinbock (1998) novamente coincidiria com a "abordagem dos direitos humanos".

\footnotetext{
${ }^{10}$ Vide GREENBERG, 1997.
} 
Também Nathwani levanta diversas objeções à "abordagem dos direitos humanos". Primeiramente, não encontramos sustentação para sua afirmação de que o preâmbulo da Convenção somente revela seu propósito de assegurar aos refugiados o usufruto de direitos e liberdade fundamentais no país de asilo e não que a violação de direitos humanos é a condição para o status de refugiado. Nathwani não considera a Convenção de forma ampla para traçar tal inferência. Isso significa analisar um excerto independentemente de todo o conteúdo da Convenção, assim como de seus objetivos e da história que culminou em sua elaboração. Fazer uma inferência baseada unicamente em uma passagem do texto parece não ser suficiente para sustentar uma afirmação tão relevante para o regime dos refugiados.

Nathwani também declara que o conceito de refugiado como aquele cujos direitos humanos foram violados leva a uma acusação ao Estado de origem, o que minaria uma suposta neutralidade do Direito Internacional dos Refugiados - necessária para que o mesmo desempenhe sua função de provimento de espaço seguro para os indivíduos perseguidos. Independentemente se a perseguição é equacionada a violação de direitos humanos, a determinação do status de refugiado nunca é um processo neutro. Ainda que se identifique perseguição a outros parâmetros, o refugiado enquanto conceito é fruto da política internacional - o refugiado é sempre aquele que não pode ou não quer valer-se da proteção de seu Estado de origem ou residência habitual devido a um fundado temor de perseguição. Isso significa que admitir um indivíduo em determinado território como refugiado implica sempre fazer uma afirmação condenatória sobre o país de origem. Ademais, foi um arranjo internacional organizado por atores políticos que definiu o conceito e que criou o regime internacional dos refugiados. E é nessa esfera altamente politizada que a proteção se concretiza. Assim, estar sujeito à política internacional é inerente ao conceito de refugiado e ao arranjo institucional desenhado para a aplicação desse instituto.

Sobre a impossibilidade de se exercer a política de imigração restritiva, a qual levaria a uma hierarquização dos direitos humanos - impossível de ser realizada satisfatoriamente -, é importante lembrar que, conquanto a percepção de que a "abordagem dos direitos humanos" traria mais refugiados para os países ricos do Ocidente, a maior parte dos refugiados do mundo não se encontra em tais territórios, nem são esses os espaços para os quais mais solicitantes de direcionam buscando refúgio. Atualmente, $80 \%$ dos refugiados encontram-se em países em desenvolvimento (UNHCR, 2011) - o ACNUR inclui entre estes os países mais pobres do globo -, e no fim do ano de 2010 havia somente na África e na América Latina, em conjunto, 401.000 solicitações de refúgio pendentes, representando $47,9 \%$ do total de 
solicitações a serem avaliadas no mundo ${ }^{11}$ (UNHCR, 2011). Ademais, como aponta Foster (2007), é importante lembrar que uma interpretação mais ampla da Convenção não teria como efeito um número maior de refugiados genuínos deixando seus países e buscando refúgio nos países ricos. As dificuldades para o alcance desses territórios continuariam as mesmas, de modo que os refugiados - como tem acontecido historicamente - continuariam a buscar refúgio em países vizinhos. Dessa forma, não se acredita que haveria um aumento do número de indivíduos solicitando refúgio nesses países, somente que se reconheceria que a um maior número de pessoas esse status seria pertinente conforme os propósitos da Convenção - e proteção a pessoas com necessidade de proteção é o princípio ao qual esses países se vincularam ao aderirem a esse documento.

Por fim, sobre a desconsideração do auto-interesse do Estado como força motivadora inexistente para a admissão de refugiados é necessário atentar para a literatura sobre regimes internacionais, ou seja, porque os Estados se engajam nesse tipo de arranjo. Diversos autores discutiram a questão da cooperação dentro da discussão sobre refúgio ${ }^{12}$, entretanto, Keohane explicita, de forma geral, o entendimento sobre esse mecanismo, ao afirmar que uma função principal dos regimes internacionais é facilitar a criação de acordos específicos em questões de substantiva importância dentro de uma área-tema coberta pelo regime (KEOHANE, 2007). Basicamente, Keohane afirma que os regimes internacionais ajudam a tornar as expectativas dos governos consistentes umas com as outras; assim, são desenvolvidos porque os atores da política internacional acreditam que com tais arranjos serão capazes de fazer acordos mutuamente benéficos que, de outra forma, seriam difícil ou impossivelmente atingidos. Isso significa dizer que não falta um componente de auto-interesse para a atuação dentro do regime dos refugiados, ao contrário, há interesses estatais que legitimam tal vinculação - e a referência no preâmbulo da Convenção a "encargos pesados" corrobora esse entendimento.

\section{Considerações Finais}

A admissão em um país como refugiado pode representar a diferença entre a vida e a morte. Foi a percepção do limbo em que os refugiados se encontram, assim como da necessidade de garantia não-discriminatória de direitos e liberdades fundamentais para balizar condições de vida dignas aos indivíduos, que levou à formulação do arranjo que hoje

\footnotetext{
${ }^{11}$ Se somarmos o total de solicitações da Ásia - considerando que o único país no continente a ser considerado rico é o Japão, o qual não possui números expressivos de refugiados nem de solicitantes -, a proporção é alterada para 56,5\%. A proporção de solicitantes na América do Norte e na Oceania é de somente 7,3\%. O que implica uma proporção de $36,2 \%$ para a Europa - continente no qual nem todos os países são considerados ricos.

12 SUHRKE, 1998; BETTS, 2011; BENZ, HASENCLEVER, 2011.
} 
caracteriza o regime internacional dos refugiados. Logo, o reconhecimento no plano internacional de que a soberania estatal e a (derivada) vinculação de cada indivíduo a um Estado soberano territorializado não podem justificar a permanência de uma pessoa que sofre (ou teme fundadamente sofrer) perseguição possibilitou o desenho da proteção internacional da pessoa humana.

Entretanto, o mundo atual é marcado pelo estabelecimento de obstáculos à mobilidade humana, e os refugiados, conquanto o caráter forçado do seu movimento internacional, têm sido envolvidos por esse contexto de restrição à movimentação, motivo pelo qual se destaca a existência de uma "crise da proteção ao refugiado". Tal limitação, no que concerne aos refugiados, tem se caracterizado, sobretudo, por um processo de determinação do status de refugiado que busca preponderantemente desqualificar as condições que determinam tal condição, ao invés de visar garantir o refúgio a pessoas com necessidade de proteção internacional. Nesse ambiente, a definição de refugiado tem sido considerada de forma restrita, para que um menor número de pessoas possa ser incluído na categoria.

Esse trabalho buscou mostrar que uma interpretação da Convenção de 1951 desvinculada da ideia de direitos humanos não se sustenta após uma análise do texto, da história e do contexto em que o contemporâneo regime internacional dos refugiados foi formulado. Demonstramos que a ideia de proteção internacional da pessoa vigente na atualidade se fundamenta em considerações de direitos humanos, de modo que negligenciado esse vínculo sequer é possível compreender o instituto do refúgio e as disposições dele derivadas. Dessa forma, a tentativa de se restringir a definição de refugiado negando a relação entre esse conceito e os padrões internacionais de direitos humanos não possui nenhuma sustentação histórica, filosófica ou conceitual. Se a garantia de direitos humanos representa o propósito principal desse mecanismo internacional, então identificamos a perseguição elemento central da definição de refugiados - como uma violação de direitos humanos. Embora, para que caracterize uma perseguição, tal violação deve apresentar características específicas, como estabelecido pela definição presente na Convenção de 1951.

Por outro lado, não podemos ignorar o contexto mundial que legitima considerações de caráter econômico ou de homogeneidade cultural para impor dificuldades ao ingresso dos refugiados nos territórios dos países. Esse contexto é o principal responsável pela clamada “crise de proteção" vinculada ao atual regime para os refugiados. Nesse panorama, identificase a necessidade de revisão das estruturas normativas e institucionais sobre as quais se apóia a 
proteção internacional - revisão para a qual é necessário o entendimento dos fundamentos que alicerçam o instituto. Cremos que alguns desses fundamentos foram explorados ao longo desse texto.

\section{Referências bibliográficas}

ALEINIKOFF, T. Alexander. The Meaning of 'persecution' in United States Asylum Law. International Journal of Refugee Law, v. 3, n. 1, p. 5-29, 1991. Disponível em: $<$ http://heinonline.org/HOL/Page?handle=hein.journals/intjrl3\&div=9\&g_sent=1\&collection= journals>. Acesso em: 26 jan. 2012.

BARRETO, L P T F. Das diferenças entre os institutos jurídicos do asilo e do refúgio. Brasília: IMDH, 2006. Disponível em: <http://www.migrante.org.br/textoseartigos.htm>. Acesso em: 26 jan. 2012.

BETTS, Alexander; LOESCHER, Gil. Refugees in International Relations. In: BETTS, Alexander; LOESCHER, Gil (eds.). Refugees in international relations. New York: Oxford University Press, 2011. p. 1-27.

BETTS, Alexander. International cooperation in the refugee regime. In: BETTS, Alexander; LOESCHER, Gil (eds.). Refugees in international relations. New York: Oxford University Press, 2011. p. 53-84.

BENZ; Sophia; HASENCLEVER, Andreas. 'Global' governance of forced migration. In: BETTS, Alexander; LOESCHER, Gil (eds.). Refugees in international relations. New York: Oxford University Press, 2011. p. 185-211.

BHABHA, Jacqueline. Embodied rights: gender persecution, state sovereignty, and refugees. Public Culture, v. 9, p. 3-32, 1996. Disponível em:

<http://publicculture.dukejournals.org/content/9/1/3.full.pdf>. Acesso em: 26 jan. 2012.

CANÇADO TRINDADE, Antônio Augusto. Tratado de Direito Internacional dos Direitos Humanos. Vol. I, Porto Alegre: Sergio Antonio Fabris Editor, 1999.

COMPARATO, Fábio Konder. A Afirmação histórica de direitos humanos. São Paulo: Saraiva, 2010.

CRISP, J. Africa's refugees: patterns problems and policy challenges. Genebra: UNHCR, 2000. Disponível em: <http://unhcr.org/3ae6a0c78.html>. Acesso em: 26 jan. 2012.

EDWARDS, Alice. Age and gender dimension in international refugee law. In: FELLER, Erika; TÜRK, Volker; NICHOLSON, Frances. Refugee protection in international law. Cambridge: Cambridge University Press, 2003. p. 46-80. Disponível em: <http://www.unhcr.org/4a1ba1aa6.html>. Acesso em: 26 jan. 2012.

FOSTER, Michelle. International refugee law and socio-economic rights: refugee from deprivation. Cambridge: Cambridge University Press, 2007. 
JUBILUT, Liliana. O Direito internacional dos refugiados e sua aplicação no ordenamento jurídico brasileiro. São Paulo: Método, 2007.

FELLER, Erika. Address to the conference of the international association of refugee law judges at Bern, Switzerland. Georgetown immigration law journal, v. 15. p. 381-389, 2001. Disponível em:

$<$ http://heinonline.org/HOL/Page?handle=hein.journals/geoimlj15\&div=23\&g_sent=1\&collec tion=journals $>$. Acesso em: 26 jan. 2012.

GOODWIN-GILL, Guy S. Asylum 2001 - a Convention and a purpose. International Journal of Refugee Law, v. 13, n. 1/2, p. 1-15, 2001. Disponível em:

<http://ijrl.oxfordjournals.org/content/13/1_and_2/1.full.pdf>. Acesso em: 26 jan. 2012

GORLICK, Brian. Human rights and refugees: enhancing protection through international human rights law. Geneva: UNHCR, 2000. Disponível em:

<http://www.unhcr.org/3ae6a0cf4.html>. Acesso em: 26 jan. 2012.

GREENBERG, Joel. Israeli accuses Palestinian Aide in killing of land-selling arabs, New York Times, New York, 2 jun. 1997. Disponível em:

$<$ http://www.nytimes.com/1997/06/02/world/israeli-accuses-palestinian-aide-in-killing-ofland-selling-arabs.html>. Acesso em: 26 jan. 2012.

HADDAD, Emma. The refugee in international society: between sovereigns. New York: Cambridge University Press, 2008.

HATHAWAY, James. Law of refugee status. Toronto: Butterworths, 1991.

IBHAWOH, Bonny. Defining persecution and protection: the cultural relativism debate and the rights of refugees. In: STEEINER, Niklaus; GIBNEY, Mark; LOESCHER, Gil (eds.). Problems of protection: the UNHCR, refugees and human rights. New York: Routledge, 2003. p. $61-75$.

JACKSON, Ivor. The 1951 Convention relating to the status of refugees: a universal basis for protection. International Journal of Refugee Law, v. 3, n. 3, p. 403-413, 1991. Disponível em: <http://ijrl.oxfordjournals.org/content/3/3/403.full.pdf>. Acesso em: 26 jan. 2012.

KEOHANE, Robert O. The Demand for international regimes. In: SIMMONS, Beth A.; STEINBERG, Richard $\mathrm{H}$ (eds.). International law and international relations. Cambridge: Cambridge University Press, 2007. p. 18-39.

LEAGUE OF NATIONS. Convention relating to the international status of refugees. 1933. Disponível em:< http://www.unhcr.org/refworld/publisher,LON,,,3dd8cf374,0.html>. Acesso em: 26 jan. 2012.

Convention concerning the status of refugees coming from Germany. 1938.

Disponível em:<http://www.unhcr.org/refworld/publisher,LON,,,3dd8d12a4,0.html>. Acesso em: 26 jan. 2012. 
LOESCHER, Gil. Human rights and forced migration. In: GOODHART, Michael. Human rights: politics and practice. New York: Oxford University Press, 2009. p. 239 - 259.

; MILNER, James. The Missing link: the need for comprehensive engagement in regions of refugee origin. International Affairs, v. 79, n. 3, p. 595-617, 2003. Disponível em: < http://www.jstor.org/stable/10.2307/3569365>. Acesso em: 26 jan. 2012.

MALKKI, Liisa H. Refugees and exile: from "refugee studies" to the national order of things. Annual Review of Antropology, v. 24, p. 495-523, 1995. Disponível em: <http://www.annualreviews.org/doi/pdf/10.1146/annurev.an.24.100195.002431>. Acesso em: 26 jan. 2012.

NATHWANI, Niraj. Rethinking refugee law. The Hague: Martinus Nijhoff Publishers, 2003.

ONU. Convenção relativa ao Estatuto do Refugiado. 1951. Disponível em: <http://www2.mre.gov.br/dai/refugiados.htm>. Acesso em: 24 fev. 2008.

ONU. Declaração Universal dos Direitos Humanos. 1948. Disponível em:

<http://www.onu-brasil.org.br/documentos_direitoshumanos.php>. Acesso em: 24 fev. 2008.

ROGERS, Rosemarie. The Future of refugee flows and policies. International Migration Review, v. 26, n. 4, p. 1112-1143, 1992. Disponível em:

<http://www.jstor.org/stable/2546877>. Acesso em: 26 jan. 2012.

STEINBOCK, Daniel J. Interpreting the Refugee Definition. 45 UCLA Law Review 733, p. 733-816, 1998. Disponível em:

$<$ http://heinonline.org/HOL/Page?handle=hein.journals/uclalr45\&div=24\&g_sent=1\&collecti on=journals >. Acesso em: 26 jan. 2012.

SURKHE, Astrid. Burden-sharing during refugee emergencies: the logic of collective versus national action. Journal of Refugee Studies, v. 11, n. 4, p. 396-415, 1998. Disponível em: <http://jrs.oxfordjournals.org/content/11/4/396.full.pdf>. Acesso em: 26 jan. 2012.

UNHCR. 2010 Statistical Yearbook. Geneva, 2011. Disponível em:

<http://www.unhcr.org/4ef9cc9c9.html>. Acesso em: 26 jan. 2012.

Handbook on procedures and criteria for determining refugee status under the 1951 Convention and the 1967 Protocol relating to the status of refugee. Geneva, 1992. Disponível em: <http://www.unhcr.org/3d58e13b4.html>. Acesso em: 26 jan. 2012.

WILSHER, Daniel. Non-state actors and the definition of a refugee in the United Kingdom: protection, accountability or culpability. International Journal of Refugee Law, v.15, n. 1, p. 68-112, 2003. Disponível em:

<http://ijrl.oxfordjournals.org/content/15/1/68.full.pdf+html>. Acesso em: 26 jan. 2012. 


\title{
DIREITOS HUMANOS E REFÚGIO: UMA ANÁLISE SOBRE O MOMENTO PÓS-DETERMINAÇÃO DO STATUS DE REFUGIADO
}

\begin{abstract}
Resumo
Embora diversos autores afirmem a existência de uma vinculação entre refúgio e direitos humanos, pouco se explora a relação entre tais direitos e a proteção ao refugiado em seu país de acolhida - aspecto fundamental do regime internacional dos refugiados. Abrindo caminho para a pesquisa sobre a temática, este trabalho visa analisar como o ACNUR tem se manifestado no que concerne aos direitos humanos dos refugiados nos seus países de asilo. Entende-se que, uma vez compreendido o regime em sua relação intrínseca com os direitos humanos, os últimos devem representar o parâmetro para a concretização da proteção internacional. Dessa forma, enfoca-se como a questão dos direitos humanos aparece nas publicações do ACNUR, nos últimos dez anos. Será possível, assim, destacar uma questão frequentemente ignorada nos estudos sobre o refúgio - a relação entre direitos humanos e refúgio após o reconhecimento do status de refugiado - tendo como foco o ACNUR, o ator de maior influência dentro do regime.
\end{abstract}

Palavras-chave: Regime internacional dos refugiados; Violação de direitos humanos; ACNUR; Política internacional.

\section{Introdução}

O regime internacional dos refugiados ${ }^{13}$ que vige na atualidade tem como fundamento filosófico principal a afirmação de direitos humanos ocorrida imediatamente após a II Guerra Mundial. A vinculação entre direitos humanos e refúgio é explorada por diversos autores ${ }^{14}$, os quais apontam a configuração atual desse instituto como resultado da afirmação internacional dos direitos humanos. Nota-se que a admissão de um refugiado por um determinado Estado materializa o reconhecimento ao indivíduo - cujo país de origem (de nacionalidade ou moradia habitual) falha em prover proteção - do direito de deixar o país e ser tutelado pela comunidade internacional. Tal reconhecimento somente foi possível após ter sido admitido que o indivíduo tem direitos, afirmados historicamente, cuja garantia visa manter sua vida, segurança e liberdade.

O refúgio pode ser caracterizado por dois momentos: o momento anterior ao reconhecimento da condição de refugiado, marcado pelas condições nos países de origem que

\footnotetext{
${ }^{13}$ Definido como o conjunto de normas, leis e instituições desenhado para proteger e assistir aos migrantes forçados que cruzaram uma fronteira internacional devido ao medo de perseguição (ROGERS, 1992) relacionado a raça, religião, nacionalidade, opinião política ou pertencimento a grupo social - ou devido a violência generalizada em seus próprios países, agressões estrangeiras, conflitos internos ou violação massiva de direitos humanos.

${ }^{14}$ GORLICK, 2003; HADDAD, 2008; HATHAWAY, 1991.
} 
levam o indivíduo a abandoná-lo e legitimam a utilização desse instituto internacional; e o posterior, ou seja, a vida dessa pessoa no país de acolhida, a denominada fase de proteção. As discussões sobre a temática do refúgio frequentemente se concentram em dois pontos: 1) a razão de sua existência como questão de interesse internacional - quando se enfatiza sua justificativa filosófica e histórica; 2) sua relação com o sistema internacional - quando se evidencia os desafios para sua manutenção enquanto instituto de proteção internacional. Em ambos os casos, a análise comumente trata da questão dos direitos humanos, mas restringe-se ao momento anterior à determinação da condição de refugiado. Assim, constata-se que um aspecto fundamental da temática é frequentemente negligenciado: a relação entre direitos humanos e refúgio no que concerne à vida do refugiado em seu país de acolhida, ou seja, no momento posterior à determinação do status de refugiado.

Admitido que os direitos humanos compõem a justificativa para a determinação da condição de refugiado - seja somente devido à aproximação filosófica ou também por entender que a violação de direitos humanos é o fator que legitima o emprego desse instituto-, compreendemos ser essencial pensar a proteção ao indivíduo (o momento após o reconhecimento desse status) também sob o prisma dos direitos humanos. Este artigo propõe, assim, focar o tema dos direitos humanos não como o parâmetro que leva ao reconhecimento da condição de refugiado, embora se reconheça esse âmbito de vinculação e o mesmo sirva como ponto de partida, mas como parâmetro para se analisar a proteção no país de acolhida. Dada a lacuna de trabalhos nesse sentido, objetivamos uma análise seminal sobre como o Alto Comissariado das Nações Unidas para os Refugiados ${ }^{15}$ - mais importante organismo de trato da questão dos refugiados, que admite ter suas origens nos direitos humanos e que seu trabalho envolve a promoção e o respeito aos mesmos - se manifesta em relação aos direitos humanos nas publicações que versam sobre os refugiados em seus países de moradia.

Duas publicações servirão de subsídio à análise: os Anuários Estatísticos, que trazem a situação geral dos refugiados no mundo a cada ano; e os Apelos Globais, publicações anuais que visam angariar recursos para a atuação do ACNUR em cada Estado, destacando as necessidades para a proteção que o ambiente específico do país coloca. Dada a impossibilidade - para esse trabalho - do exame das condições do refúgio em cada país tratado pelos Apelos Globais, toma-se como referência as publicações concernentes ao Irã, ao Quênia e à Alemanha, países vinculados ao regime internacional dos refugiados e que estão entre os países como maior número de refugiados reconhecidos ${ }^{16}$.

15 Doravante também denominado ACNUR, Escritório ou Agência.

${ }^{16}$ Os países com maior número de refugiados reconhecidos são: Paquistão, Irã, Síria, Alemanha, Jordânia, 
Objetivando uma análise atual sobre como a questão dos direitos humanos tem aparecido na agenda sobre refugiados - no que toca ao momento posterior ao reconhecimento do status de refugiado e focando o ACNUR - serão consideradas as publicações que versam sobre os últimos dez anos, de 2002 a 2011. Esse período histórico é relevante, também, por coincidir com o desenvolvimento da iniciativa "Consultas Globais" do ACNUR, lançada em 2001 e a qual consistiu de uma série de conferências com diversos atores de interesse objetivando reafirmar o comprometimento dos Estados com a implementação da Convenção de 1951, avaliar os desenvolvimentos do Direito dos Refugiados, examinar questões emergentes e tratar das questões não abarcadas pela Convenção (UNHCR, 2001b), ou seja, buscou-se a identificação do estado atual do refúgio no mundo. Acredita-se que através de tal programa foi possível mapear características e desafios contemporâneos e, assim, prover informações para a atuação do ACNUR e para sua posterior postura, inclusive no que diz respeito à temática dos direitos humanos.

Estruturaremos a análise tratando inicialmente como o ACNUR se manifesta em relação à vinculação entre direitos humanos e refúgio no que se refere ao reconhecimento do status de refugiado e à proteção em países de acolhida - quando o ACNUR trata da proteção de uma forma geral, sem considerar Estados específicos. Em seguida, como foco do estudo, analisaremos como o ACNUR se expressa no que concerne à proteção nos países de acolhida.

\section{ACNUR e direitos humanos: o reconhecimento do status de refugiado e a proteção em países de acolhida}

Nos últimos anos, a vinculação entre refúgio e violação de direitos humanos tem sido fortemente sustentada pelo ACNUR. Um ponto chave para o entendimento dessa relação refere-se ao significado de perseguição. A Agência sustenta que uma ameaça à vida ou liberdade por motivos de raça, religião, nacionalidade, opinião política ou pertencimento a grupo social é sempre perseguição. Outras sérias violações de direitos humanos - pelas mesmas razões - também constituiriam perseguição, a depender das circunstâncias específicas (UNHCR, 1992). Ademais, segundo o Escritório, decidir que um indivíduo tem "fundado

Quênia, Chade, China, Estados Unidos e Grã-Bretanha (UNHCR, 2011). Não analisamos no artigo as publicações sobre Paquistão, Síria e Jordânia, porque esses países, embora abriguem maior número de refugiados que os Estados abarcados nessa pesquisa, não aderiram à Convenção Relativa ao Estatuto de Refugiado, de 1951 - o que representaria concordância com os princípios e propósitos do regime internacional dos refugiados, que se funda nesse documento. Desse modo, não é possível utilizá-los como referência para uma análise que se baseia em parâmetros não reconhecidos, ao menos oficialmente, por esses Estados. 
temor de perseguição" é, de fato, concluir que um (ou mais) de seus direitos humanos não está sendo respeitado (UNHCR, 1995).

Em alguns textos, o ACNUR não somente declarou que a violação de direitos humanos leva ao fluxo de refugiados, como sustentou que essa é a maior causa desses movimentos (UNHCR, 1995, 1997). A Agência também se define como uma organização de direitos humanos (UNHCR, 1995, 1997) e afirma haver uma complementaridade entre a proteção ao refugiado e a promoção desses direitos (UNHCR, 1997). Enfim, é amplamente reconhecido pelo Escritório que refúgio e direitos humanos são intrinsecamente vinculados e que a violação desses direitos legitima o reconhecimento do status de refugiado.

Todavia, o ACNUR reconheceu a ligação entre diretos humanos e o refúgio não somente no que se refere à definição de refugiado, como também à sua proteção. Isso significa que o Escritório admite que, em relação à vida do refugiado em seus países de acolhida, os direitos humanos representam uma questão que não pode ser negligenciada. Entendimento manifesto em vários momentos, o Escritório tem sustentado que a proteção é sua função principal, a qual, em sentido amplo, abarca todas as atividades que buscam restabelecer a dignidade dos refugiados, protegendo seus direitos e buscando soluções duradouras dentro da estrutura de diversos tratados de direitos humanos (UNHCR, 2005a). Para o ACNUR, a proteção não pode se distanciar dos direitos humanos, não apenas porque a condição de refugiado existe devido a uma violação específica de direitos humanos, mas também em razão de três outras questões:

a) o refugiado é, antes de qualquer condição, um ser humano, ao qual diversos direitos foram reconhecidos internacionalmente. "Os requerentes de asilo e os refugiados beneficiam dos direitos e liberdades fundamentais reconhecidos nos instrumentos internacionais de direitos humanos. A protecção do refugiado deve, nessa medida, ser vista no contexto mais vasto da protecção dos direitos humanos." (ACNUR; ONU, 2002, p. 14). Portanto, muitos direitos humanos universalmente reconhecidos são diretamente aplicáveis aos refugiados - como o direito à vida, a proteção contra tortura e maus tratos, o direito à nacionalidade e à liberdade de circulação, o direito a deixar qualquer país, o direito a regressar ao seu país e o direito de não ser forçado a regressar (ACNUR; ONU, 2002).

b) a Convenção de 1951, que estabelece o conceito de refugiado e é a principal referência para o regime internacional dos refugiados, tem como fundamento a afirmação internacional de direitos humanos. Nesse sentido, a Agência declara que os direitos humanos são a fonte primária dos princípios e estruturas existentes para a proteção dos refugiados 
(UNHCR, 1998). O ACNUR entende que, como uma agência das Nações Unidas, deve assegurar que os direitos humanos de seus beneficiários sejam mantidos (UNHCR, 1997, 1995) de acordo com as obrigações internacionais dos Estados que os abrigam.

c) a própria Convenção enuncia direitos a serem observados em relação aos refugiados. O ACNUR ressalta que a proteção aos refugiados opera dentro de uma estrutura de direitos e deveres individuais e responsabilidades estatais (UNHCR, 1998). Sustenta-se que, quando reconhecidos como refugiados, há a aplicação a esses indivíduos de um regime legal especial que estabelece direitos e determina assistência e medidas de proteção, os quais, em conjunto, constituem o que é conhecido como "proteção internacional ao refugiado" (UNHCR, 2005b). A Convenção estabelece, assim, os princípios básicos para o tratamento dos refugiados (ACNUR; ONU, 2002), como o direito a não ser discriminado, o livre e fácil acesso aos tribunais, direito à educação primária e à assistência pública e a liberdade de religião.

Com base em tais considerações, entende-se que o respeito pelos direitos humanos é essencial para a proteção de refugiados (UNHCR, 1995). Nesse sentido, as ações do ACNUR são firmemente baseadas e guiadas por princípios universais de proteção ao refugiado e por padrões de direitos humanos, que reforçam a legitimidade dessas ações e que são essenciais para o alcance da segurança desses indivíduos (UNHCR, 1998).

Nesse contexto de reconhecimento da importância fundamental das questões de direitos humanos, o ACNUR vem manifestando sua preocupação em relação ao desrespeito aos direitos humanos dos refugiados. A auto-suficiência é sempre destacada como um meio necessário para se concretizar a proteção ao refugiado, e somente pode ser atingida dentro de uma estrutura de direitos civis, sociais e econômicos (UNHCR, 2005a). O ACNUR também destaca os casos em que solicitantes e refugiados são detidos ou enviados à força para zonas onde sua vida, liberdade e segurança estão ameaçadas (ACNUR; ONU, 2002). Em alguns casos, a esses indivíduos em centros de detenção é negado o acesso a tribunais e à assistência judiciária (ACNUR; ONU, 2002). Salienta-se, também, que violações à integridade física de solicitantes e refugiados têm ocorrido após a entrada no país de asilo (UNHCR, 1998).

Igualmente, a Agência preocupa-se com o aumento da intolerância, do racismo, da xenofobia, das agressões, das tensões e dos conflitos nacionais e étnicos que afetam especialmente os solicitantes de asilo e os refugiados (ACNUR; ONU, 2002) e com a impossibilidade de alguns refugiados de obter trabalho, possuir seu próprio negócio e comprar terrenos (o que remonta à necessidade de auto-suficiência para a proteção integral, a qual somente é possível em uma estrutura de direitos garantidos), situações nas quais, embora não 
sejam expulsos fisicamente à força, os refugiados podem sentir-se obrigados a partir devido a condições de vida degradantes a que são submetidos nos países de acolhimento.

\section{ACNUR e direitos humanos: a proteção nos países de acolhida}

Demonstramos que a Agência admite a vinculação entre direitos humanos e refugiados no que concerne a dois momentos: anteriormente ao reconhecimento do status de refugiado entendendo que a violação de direitos humanos se encontra no cerne das razões que forçam o indivíduo a deixar seu país; posteriormente à declaração da condição de refugiado - sendo a garantia dos direitos humanos componente essencial para a concretização da proteção no país de acolhida. Tendo isso em mente passamos à observação das publicações do ACNUR ${ }^{17}$ sobre o refúgio no mundo para identificar em quais circunstâncias se faz referência à ideia de "direitos humanos".

Anuários Estatísticos (Statistical Yearbooks)

A mais relevante constatação quando se analisa os anuários estatísticos do ACNUR de 2001 a 2010 é que a ideia de "direitos humanos" é pouco clamada pela Agência, apesar de ter esse Escritório repetidamente afirmado o vínculo existente entre direitos humanos e o trato da questão dos refugiados. Nos Anuários de 2001 a 2004, em nenhum momento se menciona o termo "direitos humanos". Na publicação sobre 2005 o mesmo é utilizado uma única vez, quando o ACNUR declara que um desafio central para a proteção internacional é assegurar a admissão, o asilo e o respeito do Estado de refúgio a direitos humanos básicos (UNHCR, 2007a, p. 61).

O Anuário referente a 2006 é aquele no qual está presente mais frequentemente a expressão "direitos humanos". Primeiramente, a publicação abandona a definição de deslocados internos em função unicamente de sua distinção em relação aos refugiados - como constava nos Anuários desde 2003 -, e os define como pessoas forçadas a deixar seus locais de origem, como resultado (entre outros possíveis fatores) de violações de direitos humanos

\footnotetext{
17 Os Anuários Estatísticos são publicações que versam sobre o refúgio - de forma ampla - no ano especificado, por esse motivo, são divulgados posteriormente ao ano tratado. Já os Apelos Globais buscam angariar fundos para as atividades do ACNUR no ano em questão, isto é, no Apelo Global 2002 são divulgados os objetivos e estratégias para 2002 e trata-se dos desenvolvimentos ocorridos no ano anterior, em 2001. Por esse motivo consideramos os Anuários de 2001 a 2010 e os Apelos Globais de 2002 a 2011.
} 
(UNHCR, 2007b). Ademais, define-se refugiados como as pessoas reconhecidas pela Convenção de 1951, o Protocolo de 1967, a Convenção da Organização da Unidade Africana de 1969, o Estatuto do ACNUR e as pessoas às quais foram garantidas formas complementares de proteção ou proteção temporária (UNHCR, 2007b, p. 16). Tais formas complementares são definidas como mecanismos para tratar as necessidades de proteção dos refugiados que não se encaixam na definição da Convenção, caso interpretada em sentido estrito, e podem ser fundamentados nas obrigações do país derivadas do Direito Internacional dos Direitos Humanos ou de provisões nacionais (constitucionais) (UNHCR, 2007b, p. 16). Os "direitos humanos" também aparecem em relação ao reassentamento, ao se sustentar que o mesmo é adequado à proteção de refugiados cuja vida, liberdade, segurança, saúde ou outros direitos humanos fundamentais estão em risco no país de refúgio (UNHCR, 2007b, p. 37). Declara-se, também, que a maioria dos fluxos de refugiados resulta de guerras ou graves violações de direitos humanos (p. 75). Por fim, o ACNUR identifica a necessidade de treinamento para as autoridades locais sobre os princípios da proteção aos refugiados, assim como do Direito Humanitário e dos Direitos Humanos para melhorar a governança da questão em alguns países (p. 77).

O Anuário de 2007 somente se distingue dos anteriores - em relação a direitos humanos - quando o ACNUR enfatiza sua atuação para a determinação do status de refugiado em regiões com fluxos forçados originados, em larga escala, de países afetados por conflitos militares ou que têm "histórico pobre de direitos humanos" (UNHCR, 2008a, p. 51). Em relação às crianças, destaca-se que as desacompanhadas e separadas têm direito à proteção sob, entre outros instrumentos, o Direito Internacional dos Direitos Humanos (p. 52).

Sobre 2008 é destacado que a proteção inclui acesso aos procedimentos de asilo, qualidade das condições de recepção, usufruto de direitos humanos, procedimentos de determinação do status de refugiado e taxas de reconhecimento justos, alcance limitado dos abusos da polícia e da xenofobia e melhor segurança e integridade física (UNHCR, 2009, p. 62). Já no que diz respeito a 2009 , ressalta-se que a responsabilidade dos países de asilo de determinar se um solicitante é refugiado é frequentemente incorporada à legislação nacional e deriva da Convenção de 1951 e de outros instrumentos de direitos humanos (UNHCR, 2010, p. 35). Também, afirma-se que a falta de acesso a trabalho, a xenofobia e os abusos de direitos humanos pelas autoridades levam a deslocamentos secundários (p. 51). O Anuário de 2010 não traz nenhuma menção nova à questão dos direitos humanos.

Observamos, portanto, que as publicações raramente utilizam a ideia de direitos humanos para se expressar em relação ao estado do refúgio no mundo. As poucas vezes em 
que tal signo é aludido se referem, frequentemente, à proteção de uma forma geral e à violação de direitos humanos como motivo que leva ao fluxo de refugiados e deslocados internos. Em algumas ocasiões, também se faz menção a instrumentos de direitos humanos como fonte da responsabilidade estatal para com os refugiados ou como conhecimento necessário para concretização da proteção. Somente em uma passagem, no Anuário de 2009, o ACNUR identifica os abusos de direitos humanos que ocorrem em países de asilo como obstáculos à proteção e geradores da necessidade da busca por proteção em outro território.

Uma segunda constatação é que o ACNUR, em algumas passagens dos textos, se expressa em termos de "direitos" (embora considerando a quantidade total de publicações analisadas não se pode afirmar que mesmo essa ideia seja invocada recorrentemente). Nesses casos, trata-se principalmente de três questões: reassentamento, integração local e crianças. No que diz respeito ao reassentamento, é frequente nos Anuários a afirmação de que os refugiados reassentados normalmente têm acesso a um conjunto de direitos sociais, econômicos e legais (UNHCR, 2005c, 2006a, 2007a, 2007b). Em relação à integração local, sustenta-se que por meio dessa solução é provido aos refugiados um conjunto de direitos pelo país de acolhida amplamente proporcionais àqueles desfrutados pelos cidadãos (UNHCR, 2005c, 2006a, 2007a). Também, afirma-se que a integração econômica nesses países envolve o acesso aos direitos sociais e econômicos presentes na Convenção de 1951, o que inclui o direito a buscar meios de sobrevivência sustentáveis e se engajar em atividades de geração de renda (UNHCR, 2005c, 2006a, 2007a). No que concerne às crianças, ressalta-se a necessidade de se garantir seu direito à educação (UNHCR, 2007a, 2007b, 2008a) e que o ato de se registrar uma criança é um meio de se assegurar seus direitos, como acesso a saúde e educação, proteção e limite etário legal para atividades como emprego e recrutamento militar (UNHCR, 2007b, 2011).

O signo dos "direitos" também aparece em relação a outras questões, como, à importância do registro para os refugiados, por fornecer proteção contra o refoulement ${ }^{18} \mathrm{e}$ acesso a direitos básicos (UNHCR, 2010a); a questões de gênero, salientando a necessidade de se assegurar o usufruto de direitos a todos os refugiados - mulheres e homens (UNHCR, 2007b, 2011); ao direito ao trabalho, quando se destaca que muitos refugiados não podem trabalhar sem que possuam licença de trabalho (UNHCR, 2008a); à existência de assunções negativas sobre os refugiados, como a estigmatização relacionada ao HIV/AIDS, que podem

\footnotetext{
${ }^{18}$ Princípio expresso no artigo 33 da Convenção de 1951: "Nenhum dos Estados Contratantes expulsará ou rechaçará, de forma alguma, um refugiado para as fronteiras dos territórios em que sua vida ou liberdade seja ameaçada em decorrência de sua raça, religião, nacionalidade, grupo social a que pertença ou opiniões políticas." (ONU, 1951).
} 
minar os direitos desses indivíduos e devem ser desconstruídas (UNHCR, 2011) e ao direito de asilo, o qual deve ser sempre garantido (UNHCR, 2008a).

Global Appeals (Apelos Globais)

Como justificado na introdução, utilizamos como referências as publicações concernentes ao Irã, Quênia e Alemanha, dada a impossibilidade - para este trabalho - de se analisar o Apelo de cada Estado tratado individualmente (ou por área geográfica) pelo ACNUR. Esses figuram entre os dez países com maior número de refugiados reconhecidos, e, ao contrário de outros que porventura abriguem maior quantidade de refugiados, vinculam -se de uma forma mais integral ao atual regime internacional dos refugiados.

\section{$\operatorname{Ir} \tilde{a}$}

Nas publicações examinadas, em nenhum momento o ACNUR se referee a "direitos humanos" quando trata das questões de refúgio no Irã. Por outro lado, o termo "direitos" aparece em algumas passagens dos textos. No que se refere a 2001, o ACNUR menciona "direitos" apenas quando entre seus principais objetivos inclui promover a implementação da legislação sobre os direitos dos estrangeiros (UNHCR, 2002b, p. 145) - objetivo também estabelecido no Apelo 2003, o qual, mais específico, determina como propósito o apoio ao governo para o planejamento de uma estrutura legal que garanta aos refugiados o direito ao trabalho e o acesso à saúde e à educação (UNHCR, 2002b, p. 187). Para 2005, a Agência determina como uma de suas estratégias a cooperação com o governo para estabelecer um procedimento nacional para determinação do status de refugiado construído em torno de um conjunto acordado de direitos e obrigações atrelado a essa condição (UNHCR, 2004b, p. 224). Também afirma que os afegãos deportados terão o direito de apresentar uma reivindicação por proteção continuada no Irã e de tê-la determinada de acordo com padrões internacionais (p. 226).

No que toca a 2006, o Escritório estabelece como um dos objetivos centrais o aumento da proteção de solicitantes e refugiados através do monitoramento e promoção do respeito a seus direitos (UNHCR, 2005d, p. 249). O comentário, em termos de "direitos", tecido sobre 2005 concerne ao fato de que os refugiados nesse país não têm o direito legal a trabalhar assalariadamente (p. 251). Sobre os desenvolvimentos em 2006, destaca-se a recusa do governo em garantir ao ACNUR o direito de determinar o status de refugiado a solicitantes individuais, o que complica a estrutura de proteção do país (UNHCR, 2006b, p. 211). 
A estratégia a ser desenvolvida em 2009 também inclui a questão referente à garantia do asilo, com a afirmação de que serão feitas novas negociações com o governo iraniano para que o mesmo continue a assegurar o asilo a refugiados registrados, enquanto necessário, e o seu acesso a direitos e serviços (UNHCR, 2008b, p. 260). Nos Apelos para 2010 e 2011, o termo "direitos" somente é utilizado quando se distingue os chamados "grupos de direitos e objetivos" 19 para estabelecer a previsão de orçamento.

\section{Quênia}

Nas publicações que visam estabelecer o orçamento para as operações no Quênia, alude-se a "direitos humanos" em dois momentos: no Apelo Global 2003, quando a Agência afirma que, quando necessário, aumentará o entendimento do governo sobre as disposições de relevantes instrumentos de direitos humanos (UNHCR, 2002b, p. 109) e para 2010, quando, em referência ao ano anterior, se relata a chegada de refugiados escapando de violência e violações de direitos humanos (UNHCR, 2009b, p. 74). Por outro lado, invoca-se ainda menos - quando comparado às publicações sobre o Irã - a ideia de "direitos".

Em relação a 2003, o ACNUR assevera que consultas lhe estão sendo realizadas pelo governo sobre os componentes relacionados a direitos da Carta dos Refugiados (Refugee Bill) (UNHCR, 2003, p. 98). Também é destacado que em 2010 foi adotada uma nova constituição, a qual reconhece os direitos das pessoas de interesse do ACNUR, notadamente refugiados e apátridas (UNHCR, 2010b, p. 72). Para 2010, um dos objetivos centrais é a promoção de melhor acesso a serviços públicos e outros direitos, como o direito ao trabalho e à naturalização, para refugiados urbanos (UNHCR, 2009b, p. 75). E para 2011 destaca-se como estratégia o trabalho junto ao governo queniano para assegurar os direitos dos refugiados (UNHCR, 2010b, p. 73).

\section{Alemanha}

As publicações sobre a Alemanha apresentam uma diferença relevante em relação àquelas sobre o Irã e o Quênia: não há uma publicação específica buscando levantar fundos para as atividades do ACNUR que verse sobre a situação particular em seu território. Os Apelos Globais da Europa geralmente são divididos por áreas geográficas, não tratando dos

\footnotetext{
${ }^{19}$ Grupo de direitos e objetivos: ambiente de proteção favorável; processos justos de proteção e documentação; segurança contra violência e exploração; necessidades básicas e serviços essenciais; participação da comunidade e auto-manejo; soluções duradouras; relações externas; logística e apoio a operações (UNHCR, 2009b, p. 15-16).
} 
países individualmente, mas dando um panorama geral da situação dos refugiados nas subregiões e estabelecendo objetivos e estratégias para o ano seguinte ${ }^{20}$.

As publicações referentes aos anos de 2002, 2003 e 2006 a 2010 simplesmente não falam em "direitos humanos", ou mesmo em "direitos". Traçando prospecções para 2004, estabelece-se, como objetivo estratégico, a manutenção da equivalência dos sistemas de asilo na Europa com os princípios do Direito Internacional dos Direitos Humanos (UNHCR, 2003, p. 243). O ACNUR ainda expressou sua preocupação com os padrões desapontadores que foram estabelecidos pela harmonização resultante das diretivas europeias sobre asilo, os quais, em alguns casos falham em conformar com princípios do Direito Internacional dos Direitos Humanos (p. 243). Ciente das preocupações estatais com o nexo migração-asilo, a Agência afirma trabalhar com os países para desenvolver medidas de manejo e controle de migração que respeitem integramente o direito de buscar asilo (p. 245) - preocupação reafirmada no Apelo 2005 (UNHCR, 2004b, p. 298). Em relação a 2011, a única menção a “direitos" referese ao futuro fortalecimento da análise do Escritório sobre o perfil e os direitos de nãocidadãos (UNHCR, 2010b, p. 293).

A descrição acima sobre como a questão "direitos humanos/direitos" aparece nas publicações analisadas - juntamente com o exame dos outros documentos do ACNUR que falam sobre a proteção internacional - leva-nos a uma conclusão: no que se refere à proteção em países de acolhida, ou seja, à proteção de modo geral, o ACNUR tem reafirmado a necessidade de uma perspectiva de direitos humanos para que a mesma seja realizada de acordo com seus objetivos; já no que concerne à descrição e análise sobre o ambiente em que o refúgio se concretiza, ou seja, quando se trata da proteção nos países de acolhida aqui apresentados, frequentemente a Agência não se expressa em termos de "direitos humanos". Assim, o estudo empreendido sugere que o ACNUR pouco alude à ideia de "direitos humanos" e que, se em alguns momentos faz referência a "direitos", também não se pode sustentar que essa é uma palavra de uso recorrente na literatura examinada, principalmente para tratar da situação de vida dos refugiados nos países de acolhida.

Outra questão à qual deve ser dado destaque relaciona-se ao fato de que na maioria dos casos em que se menciona "direitos”, não é evidente se a intenção é se referir a direitos legalmente reconhecidos no país, aludir aos direitos declarados especificamente na Convenção de 1951 ou se manifestar sobre os "direitos humanos" reconhecidos em diversos

\footnotetext{
${ }^{20}$ Os Apelos entre 2002 e 2009 que tratam da Alemanha, referem-se a toda Europa Ocidental; já aqueles para os anos de 2010 e 2011 abarcam, numa mesma publicação, além da Europa Ocidental, o norte e o sul da Europa.
} 
instrumentos internacionais e que servem de base para a existência e concretização dos objetivos do regime; de modo que diversas interpretações são possíveis. Essa pluralidade de entendimentos possíveis torna-se ainda mais evidente quando o ACNUR afirma que o governo iraniano se recusa a garanti-lo o direito de determinar o status de refugiado (UNHCR, 2006b) - apontando para uma atribuição legal concedida pelo o Estado, mas também denominada de "direito".

Nas publicações analisadas, a ideia de "direitos humanos" é pouco invocada e quando o é, se refere, preponderantemente, às violações que levam os indivíduos à fuga, ou seja, à vinculação entre direitos humanos e refúgio no momento anterior ao reconhecimento da condição de refugiado (e como justificativa para tal); em algumas outras poucas vezes, aludese à necessidade de ampliação do conhecimento das autoridades sobre os direitos humanos. A noção de "direitos humanos" é mais frequentemente invocada quando o Escritório destaca sua importância de para a proteção, isto é, quando aborda a questão de maneira ampla, sem se referir a um país específico de asilo: quando se afirma que um desafio central para a proteção internacional é assegurar a admissão, o asilo e o respeito do Estado por direitos humanos básicos (UNHCR, 2007a); ao sustentar que a proteção inclui o usufruto de direitos humanos (UNHCR, 2009a); quando se assevera que abusos de direitos humanos pelas autoridades dos países de acolhida levam a movimentos secundários de refugiados (UNHCR, 2010a).

Outras observações merecem destaque: nas publicações sobre o Irã em momento algum se fala em "direitos humanos" e nas publicações sobre a Europa Ocidental esses somente são mencionados ao se apontar a necessidade de criação de sistemas de asilo cujos princípios sejam equivalentes aos do Direito Internacional dos Direitos Humanos. No caso do Quênia, a expressão também não é empregada no tocante ao ambiente de refúgio, somente no que concerne aos motivos que levam ao fluxo para seu território e à necessidade de melhor familiaridade do governo com a área dos direitos humanos. Tais constatações levam ao questionamento: inexistem, são efêmeros ou de baixa intensidade os problemas vinculados ao desrespeito aos direitos humanos dos refugiados, de modo geral (já que são pouco mencionados nos Anuários), e nesses países, especificamente (uma vez que também são pouco mencionados nas publicações especificas) ${ }^{21}$ ?

A resposta para a pergunta é não. Mesmo não se utilizando do signo dos "direitos humanos", os problemas vinculados ao desrespeito aos direitos humanos dos refugiados nos

\footnotetext{
21 Rubio (2010) afirma que se estabeleceu uma concepção pós-violatória dos direitos humanos. Devido a essa concepção, os direitos humanos somente são aludidos em caso de violação, o que significa que nas circunstâncias em que não há violação dificilmente a noção de "direitos humanos” será ressaltada.
} 
seus países de acolhida estão presentes nessas publicações, principalmente nos Apelos Globais. Em relação ao Irã, o ACNUR destaca como objetivo - a cada ano - assegurar a proteção efetiva dos refugiados. Fala-se em alcançar condições de vida que sigam padrões satisfatórios, sendo, para isso necessário tratar das necessidades essenciais dos refugiados. Essas afirmações de caráter geral feitas sobre as condições de vida dos refugiados nesse país levam-nos a constatar uma situação em que os padrões de vida não são satisfatórios e a proteção não vem se realizando de forma efetiva. Algumas afirmações específicas discriminam melhor a situação: problemas relacionados ao acesso à educação e à saúde; o trabalho sendo vinculado a uma licença e restrito a algumas áreas de atuação, além da imposição de taxas municipais aos refugiados. O ACNUR afirma que muitos refugiados vivem sob condições socioeconômicas difíceis (UNHCR, 2008b) e a auto-suficiência é colocada a cada ano como um dos principais objetivos alvejados pela Agência.

Ademais, ao lado das limitações socioeconômicas explicitadas, os refugiados no Irã ainda sofrem com outras graves restrições a seus direitos. A liberdade de movimento dos refugiados tem sido limitada, pois aos refugiados não é permitido moradia em algumas províncias ou regiões (UNHCR, 2007c) (as chamadas "no-go areas"). Centenas de afegãos têm sido submetidas à prisão, detenção e deportação e há relatos de refugiados registrados entre os mesmos (UNHCR, 2006b). Por fim, a imposição de taxas municipais aos refugiados afegãos viola o artigo $29^{\circ}$ da Convenção de 1951 e há uma distinção evidente no trato direcionado a refugiados afegãos e iraquianos (UNHCR, 2007c). No caso da liberdade de movimento, assim como no que se refere ao trabalho remunerado, de fato, o Irã não age em contraposição às obrigações derivadas da Convenção de 1951, pois esse país a adotou com reservas aos artigos $17^{\circ}, 23^{\circ}, 24^{\circ}$ e $26^{\circ}$, o que lhe permite esse tipo de tratamento em relação aos refugiados. O mesmo, todavia, não pode ser afirmado no que diz respeito às prisões, deportações e imposição de taxas municipais. Vemos, portanto, violações de princípios básicos da proteção internacional como o non-refoulement (deportação), além de violações à liberdade de movimento e à liberdade de forma geral (prisão e detenção) - fatos que colocam em risco a vida, liberdade e segurança desses indivíduos.

A situação dos refugiados no Quênia é ainda mais grave. O ACNUR sempre destaca entre seus objetivos principais assegurar asilo seguro e digno para todos nesse país, além de preservar padrões mínimos de vida e garantir que os refugiados tenham acesso a serviços essenciais. O contínuo corte de financiamento tem impedido atividades em importantes setores, como proteção, treinamento vocacional, atividades de geração de renda, educação, distribuição de comida e provisão de abrigo e cuidados médicos, sendo que, por esse motivo, 
a situação dos quatro últimos permanece abaixo de padrões mínimos aceitáveis (UNCHR, 2003). O ACNUR estabelece sempre como meta prover serviços necessários para que os refugiados tenham uma vida digna. Nesse sentido, são assustadoras as afirmações como "O ACNUR buscará atingir padrões mínimos de assistência humanitária pelo menos na proteção e nas atividades de salvamento e manutenção da vida." (UNHCR, 2004b). A taxa de mánutrição aguda global permanece em 12\% nos campos (UNHCR, 2010b). Nos campos de Kakuma, 75\% dos refugiados vivem em habitação adequada, em Dadaab essa proporção é de somente 17\% (UNHCR, 2010b).

No Quênia, o cerne da política para os refugiados é a concretização da restrição à sua liberdade de movimento: a política de encampamento. Os refugiados são forçados a viverem em locais com clima quente e seco, com recursos naturais limitados, não podendo cultivar a terra ou buscar emprego fora dos campos (UNHCR, 2002b); por esse motivo são totalmente dependentes do ACNUR para proteção e assistência material. Ademais, não têm acesso a tribunais $^{22}$, a maior parte (75\%) não tem documentação (UNHCR, 2009b), a situação de segurança dentro e no entorno dos campos é precária (UNHCR, 2002b) e há uma hostilidade entre os refugiados e as comunidades receptoras que pode facilmente explodir em violência, colocando suas vidas em risco (UNHCR, 2002b). Além disso, em janeiro de 2007, as autoridades quenianas fecharam a fronteira com a Somália, motivo pelo qual (embora alguns tenham conseguido acessar o Quênia) refugiados somalis foram privados de buscar asilo nesse território (UNHCR, 2007c, p. 147).

Em relação à Alemanha, como explicitamos, a Agência expressa suas preocupações no que concerne à proteção dos refugiados em toda a área da Europa Ocidental. Para essa região, o ACNUR destaca a preocupação com a necessidade de se manter a qualidade do asilo e o acesso ao território; pois aumentam as medidas restritivas ao acesso de estrangeiros a esses países, de modo que os refugiados podem ser privados de buscar proteção nesses Estados estando, assim, ameaçados os princípios do asilo e do non-refoulement. Outros problemas, sempre mencionados nas publicações do ACNUR, dizem respeito à detenção de solicitantes de refúgio, a qual frequentemente ocorre em instalações subpadronizadas (UNHCR, 2008b) uma clara violação à liberdade e à segurança do indivíduo com necessidade de proteção internacional. Outra problemática repetidamente destacada relaciona-se à questão da xenofobia, do racismo e da intolerância - que afetam os estrangeiros de forma geral -, que representa, hoje, um dos principais desafios para a proteção ao refugiado na região (UNHCR,

\footnotetext{
22 O ACNUR tem buscado alterar essa situação através da promoção de cortes móveis (UNHCR, 2009b).
} 
2005d), além de ser um grande empecilho para a integração dos mesmos em seus países de asilo e, assim, para o usufruto de direitos.

Logo, observamos que princípios básicos, como o non-refoulement - e, consequentemente, o direito à vida -, estão sendo violados nos países em questão. Diversas violações de direitos humanos, algumas análogas àquelas que levam ao reconhecimento da necessidade internacional de proteção, como o direito à liberdade e à segurança, são verificadas nos países de asilo. Essas afirmações decorrem da análise das publicações do ACNUR apresentadas em nosso trabalho; contudo - conquanto o fato de que em diversos momentos o Escritório enfatiza a necessidade de uma perspectiva de direitos humanos para a concretização da proteção e que o instituto do refúgio consiste de uma relação intrínseca de fundamento e complementaridade ao campo dos direitos humanos -, essa mesma postura não pôde ser observada no que se refere à sua descrição e análise sobre as condições de vida dos refugiados nos seus países de asilo. Se, ao tratar da proteção de uma forma geral, a Agência enfoca fortemente a questão dos direitos humanos, faria sentido, seria coerente, tratar dessa mesma questão nos países de asilo - afinal, essa proteção abstrata para a qual se advoga uma perspectiva de direitos humanos somente se concretiza no mundo real dos países de acolhida. Todavia, não é esta a situação observada nas publicações abarcadas por esse trabalho, o que leva a um novo questionamento: Por que há essa distinção em relação à forma como esse organismo se expressa em relação à mencionada vinculação?

\section{O papel da política internacional}

Uma resposta a essa pergunta poderia relacionar-se às situações concretas com as quais o ACNUR tem que lidar. Embora reconheça o fundamento de direitos humanos intrínseco à proteção, essa somente se concretiza em espaços soberanos e territorializados, denominados Estados. O ACNUR tem que lidar com as diferenças sociais, culturais, econômicas, jurídicas, normativas que cada um desses contextos representa. Dessa forma, seria possível afirmar que a omissão em invocar uma noção de "direitos humanos" para a proteção se basearia no fato de que existe a possibilidade de que o país em questão não reconheça esses direitos sob a mesma perspectiva da Agência. Entretanto, essa justificativa é desconstruída ao tecermos alguns comentários sobre os países aqui tratados: 1) todos os três países são signatários da Convenção de 1951 que referencia a Declaração Universal de 
Direitos Humanos como um de seus fundamentos ${ }^{23}$; 2) os três países são signatários dos mais importantes instrumentos internacionais de direitos humanos: o Pacto Internacional de Direitos Civis e Políticos e o Pacto Internacional de Direitos Econômicos, Sociais e Culturais; 3) no caso da Alemanha, trata-se de um país completamente integrado ao regime internacional dos direitos humanos, um país ocidental, que compartilha a mesma ideia de direitos humanos propagada pelo Alto Comissariado - assim como todos os países abarcados pela publicação referente à Europa Ocidental -, porém, mesmo em tais publicações não se dá maior destaque à questão dos direitos humanos para a proteção.

Embora o estudo não seja definitivo, dada a limitação de documentos analisados dentre uma infinidade e complexidade de aspectos da proteção internacional e da atuação do ACNUR dentro desse regime, o que observamos remete a uma situação na qual esse organismo se exime de invocar a ideia de direitos humanos para a concretização da proteção nos países de asilo, em contraposição à sua própria argumentação de que esse é um aspecto essencial desse arranjo internacional. Acreditamos que a ausência de referências aos direitos humanos nas análises da situação dos refugiados nos países de acolhida feitas pelo ACNUR ultrapassa um simples descompasso entre a Agência e o país no que toca à compreensão da noção de direitos humanos. Sem dúvida, a configuração do sistema internacional - baseado no Estado soberano, o qual modela o regime internacional dos refugiados - exerce uma força fundamental na forma como o Escritório vem tratando essa questão.

Nesse sentido, é necessário atentar para um fator central no contexto considerado: a política internacional. Observando-se a emergência do regime internacional dos refugiados é possível inferir que foi uma escolha política que levou à criação desse arranjo internacional, e é numa esfera altamente politizada - em que interesses políticos moldam a compreensão dos fatos e as atitudes então derivadas - que a proteção ao refugiado se realiza. Assim, procede a afirmação (BETTS, 2009) de que os movimentos de refugiados são inerentemente políticos (envolvendo interesses concorrentes e direitos de cidadãos e não-cidadãos) e inerentemente internacionais (envolvendo o movimento transfronteiriço de pessoas).

Um aspecto fundamental da política internacional relacionada ao refúgio é destacado por Loescher (2003), ao afirmar que o ACNUR mantém um arriscado equilíbrio entre a proteção aos refugiados e as prerrogativas e interesses dos Estados, dependendo dos governos

\footnotetext{
${ }^{23}$ Embora saibamos que a adoção de instrumentos internacionais de direitos humanos não seja suficiente para estabelecermos afirmações definitivas sobre o entendimento de um determinado país sobre a questão, acreditamos ser essa a forma mais objetiva e adequada de se entender sua postura dentro do contexto aqui apresentado.
} 
soberanos de acolhida para o acesso a, e a ordem no, seu ambiente operacional. Similarmente, Chimni (1998) sustenta que toda abordagem referente aos refugiados tem que lidar com a tensão entre a prerrogativa dos Estados soberanos de especificar as regras de admissão e as necessidades de pessoas cuja vida e liberdade estão em risco. Malkki (1995) enfatiza que a preponderância da preocupação com a soberania estatal traz consequências negativas para a proteção, como a naturalização e a razoabilidade do fechamento de fronteiras ao asilo e a necessidade de controle do movimento de pessoas que estão "fora de seus lugares".

Embora pareça evidente o fato de que a política internacional é um fator altamente influenciador e - nesse caso - que constrange os desenvolvimentos no campo do regime internacional analisado, esse é um aspecto frequentemente negligenciado pelos estudiosos da temática, como apontam diversos autores (BETTS, LOESCHER, 2011; HADDAD, 2008; SCALETTARIS, 2007). Comumente se identifica os interesses estatais e a ideia de soberania como fatores essenciais para os rumos da proteção internacional à pessoa, entretanto, pouco se demonstra como agem e em qual medida. A análise apresentada sobre as publicações do ACNUR fornece subsídios interessantes para se enfocar a questão e discutir alguns aspectos envolvidos pela problemática.

Como afirmamos, o ACNUR tem sempre, em sua atuação, que buscar um equilíbrio entre a proteção ao refugiado e os interesses do país de acolhida. As publicações da Agência analisadas demonstram uma negligência em relação ao signo dos "direitos humanos", em contraposição não apenas à defesa do Escritório da relevância da questão, como também, e principalmente, em contraposição à realidade - a existência de violações de direitos humanos dos refugiados nos países de acolhida. Acreditamos que uma questão central para o entendimento da ausência da ideia de direitos humanos nessas publicações se relaciona a esse equilíbrio necessário à sua atuação e o papel dos direitos humanos na ordem internacional.

Depois da II Guerra Mundial se formou um consenso, demonstrado na Declaração Universal de 1948, de que os direitos dos indivíduos eram tema de interesse da sociedade internacional (SIMMONS, 2009). Gradualmente, as normas internacionais de direitos humanos tornaram-se amplamente aceitas pelos Estados e entendidas como imperativas, conquanto a falta de mecanismos de enforcement e a existência de interesses nacionais que moldam a forma como os países tratam as questões de direitos humanos em seu próprio território (DONNELLY, 2003). Tal força normativa faz com que os Estados, mesmo quando indispostos a traduzir a interdependência moral refletida na ideia de direitos humanos em ações, não estejam dispostos a voltar a tratar as práticas nacionais de direitos humanos como questão independente da observação e avaliação internacional. Nesse sentido, a ampla adoção 
de instrumentos de direitos humanos reflete o alinhamento das preferências dos Estados ao conteúdo dos tratados internacionais que versam sobre a temática (SIMMONS, 2009) e a concordância a respeito da relevância dos mesmos para uma governança adequada da questão.

Embora seja amplamente aceita a relação entre direitos humanos e refúgio, ainda não é consensual a compreensão de que os primeiros devem constituir parâmetro para a determinação do status de refugiado (FOSTER, 2007). Apesar dos mais de 60 anos de existência do regime internacional dos refugiados fundado na Convenção de 1951, ainda é amplo o debate a respeito dessa vinculação e, frequentemente, tenta-se desconstruir tal relação visando exatamente evitar o imperativo moral que os direitos humanos representam. Acreditamos ser possível que esse também constitua o fator central para a postura do ACNUR de evitar tratar das condições dos refugiados em seus países de acolhida em termos de direitos humanos, apesar da manifesta defesa pela Agência da existência desse vínculo.

Devido ao reconhecimento de que os direitos humanos representam normas amplamente aceitas que devem ser observadas pelos Estados é que invocar os direitos humanos nas suas publicações desconstruiria o equilíbrio necessário ao trabalho do ACNUR nos países de acolhida. Falar em direitos humanos significa apelar para um imperativo mais forte que o humanitarismo comumente declarado como responsável pela formulação do arranjo internacional para a questão dos refugiados. E a parcimônia tem sido uma das estratégias para implementação de suas políticas e concretização da proteção aos refugiados. Desse modo, mesmo a forma como essa Agência se expressa em relação à vida dos refugiados nos países de asilo é influenciada pela política internacional.

Betts (2009) destaca que a relação entre migração forçada e política internacional pode ser identificada em três diferentes níveis: causas, consequências e respostas. O estudo empreendido demonstra essa relação em todos os níveis.

No nível das causas, evidencia-se o sistema internacional, o qual se baseia na figura do Estado territorializado sem o qual o refugiado enquanto conceito não existiria (HADDAD, 2008), uma vez que para tal condição é necessária a transposição de fronteiras internacionais. É exatamente devido à existência de um país de acolhimento, o qual tem como prerrogativa a soberania estatal, que há a demanda de busca por equilíbrio para o exercício do trabalho do ACNUR - prover proteção aos refugiados.

No que se refere às consequências, é necessário ressaltar que a presença dos refugiados em um determinado país é responsável pela geração de conflitos no interior da comunidade nacional. Tais conflitos podem ser derivados, por exemplo, da expansão do conflito de um país vizinho devido ao fluxo de refugiados ou da quebra de uma (existente ou 
percebida) homogeneidade social, cultural e econômica. Em ambos os casos, são as frequentes considerações sobre insiders e outsiders que moldam a forma como os refugiados serão tratados no ambiente de "acolhida" e, consequentemente, as suas condições de vida. Sem dúvida, um dos motivos para a dificuldade de concretização da proteção integral no país de asilo - que leva o ACNUR a andar na "corda bamba" (LOESCHER, 2003) - diz respeito a esse conflito, em que o lado dos não-cidadãos é comumente preterido.

Por fim, no que concerne às respostas, um aspecto chave da temática é como a cooperação internacional - meio avaliado como mais adequado para se lidar com a questão dos refugiados - delineou um regime o qual, não obstante todo o sucesso alcançado nesses anos de existência, sofre de um problema profundo: a falta de mecanismos de enforcement. Dada essa lacuna, o ACNUR depende fortemente da persuasão para a concretização da proteção, para a qual é necessário o mencionado equilíbrio.

\section{Considerações finais}

Os interesses dos Estados soberanos, mutáveis como são, determinam, conquanto os compromissos assumidos internacionalmente, os rumos da proteção aos refugiados. Haddad (2008) aponta, de forma pertinente, que moralmente falando, as demandas humanitárias do oferecimento de proteção internacional ao refugiado devem superar quaisquer outras preocupações, mas a realidade mostra que é impossível separar o ético do político no mundo moderno de relações interestatais. Assim, a falha em responder adequadamente aos fluxos de refugiados é largamente influenciada pela natureza política e internacional do problema, sendo essa refletida em todos os aspectos que envolvem a temática. É possível, então, perceber que até mesmo as publicações que visam evidenciar a questão e garantir apoio para, dessa forma, fornecer uma proteção adequada aos refugiados são permeadas por considerações de política internacional. Tais considerações, portanto, moldam a forma como o ACNUR se manifesta em relação às condições de vida dos refugiados nos países de acolhida - obscurecendo seu entendimento sobre a importância das questões de direitos humanos para a proteção dos refugiados e, consequentemente, legitimando, de alguma forma, o nãoreconhecimento de sua relevância.

A proteção efetiva dos refugiados apenas é possível a partir da compreensão de seus fundamentos e de todos os fatores intervenientes. Indubitavelmente, as dinâmicas da política internacional representam um fator essencial no contexto apresentado e, por esse motivo, é 
necessário suprir as lacunas de pesquisa na área, deixando de somente apontar questões e passando a analisá-las. Esse é um dos caminhos possíveis para a superação da tão mencionada “crise da proteção internacional" e o estabelecimento de um espaço efetivo de proteção para os refugiados.

\section{Referências bibliográficas}

ACNUR; ONU. Direitos humanos e refugiados. Lisboa, 2002. Disponível em:

<http://www.gddc.pt/direitos-humanos/Ficha_Informativa_20.pdf>. Acesso em: 26 jan. 2012.

BETTS, Alexander. Forced migration and global politics. Chichester: Wiley-Blackwell, 2009.

BETTS, Alexander; LOESCHER, Gil. Refugees in International Relations. In: BETTS, Alexander; LOESCHER, Gil (eds.). Refugees in international relations. New York: Oxford University Press, 2011. p. 1-27.

CHIMNI, B. S. The Geopolitics of refugee studies: a view from the south. Journal of Refugee Studies. v. 11, n. 4, p. 350-374, 1998. Disponível em:

<http://jrs.oxfordjournals.org/content/11/4/350.2.full.pdf>. Acesso em: 26 jan. 2012.

DONNELLY, Jack. Universal human rights in theory and practice. New York: Cornell University Press, 2003.

FOSTER, Michelle. International refugee law and socio-economic rights: refugee from deprivation. New York: Cambridge University Press, 2007.

GORLICK, Brian. Refugee protection in troubled times: reflections on institutional and legal developments at the crossroads. In: STEEINER, Niklaus; GIBNEY, Mark; LOESCHER, Gil (eds.). Problems of protection: the UNHCR, refugees and human rights. New York: Routledge, 2003. p. $79-99$.

HADDAD, Emma. The refugee in international society: between sovereigns. New York: Cambridge University Press, 2008.

HATHAWAY, James. The law of refugee status. Toronto: Butterworths, 1991.

LOESCHER, Gil. UNHCR at fifty: refugee protection and world politics. In: STEINER, Niklaus; GIBNEY, Mark; LOESCHER, Gil (eds.). Problems of protection: the UNHCR, refugees, and human rights. New York: Routledge, 2003. p. 3-18.

MALKKI, Lisa. Refugees and exile: from 'refugee studies' to the national order of things. Annual Review of Anthropology. v. 24, p. 495-523, 1995. Disponível em: <http://www.annualreviews.org/doi/pdf/10.1146/annurev.an.24.100195.002431>. Acesso em 26 jan. 2012. 
ONU. Convenção Relativa ao Estatuto do Refugiado. 1951. Disponível em: <http://www2.mre.gov.br/dai/refugiados.htm>. Acesso em: 26 jan. 2012.

ROGERS, Rosemarie. The Future of refugee flows and policies. International Migration Review. v. 26, n. 4, p. 1112-1143, 1992. Disponível em:

<http://www.jstor.org/stable/2546877>. Acesso em: 26 jan. 2012.

RUBIO, David Sanchéz. Fazendo e desfazendo direitos humanos. Santa Cruz do Sul: Edunisc, 2010.

SCALETTARIS, Giulia. Refugee studies and the international refugee regime: a reflection on a desirable separation. Refugee Survey Quarterly, v. 26, n. 3, p. 36-50, 2007. Disponível em: < http://rsq.oxfordjournals.org/content/26/3/36.full.pdf+html>. Acesso em: 26 jan. 2012.

SIMMONS, Beth. Mobilizing for human rights: international law in domestic politics.

Cambridge: Cambridge University Press, 2009.

UNHCR. Development assistance for refugees (DAR) programmes. Mod. I. Geneva, 2005a. Disponível em: <http://www.unhcr.org/refworld/docid/428076704.html>. Acesso em: 26 jan. 2012.

Global Appeal 2002. Geneva, 2001a. Disponível em:

<http://www.unhcr.org/4a0bdd2d6.html>. Acesso em: 26 jan. 2012.

. Global Appeal 2003. Geneva, 2002b. Disponível em:

<http://www.unhcr.org/4a0bd6cc6.html>. Acesso em: 26 jan. 2012.

Global Appeal 2004. Geneva, 2003. Disponível em:

<http://www.unhcr.org/4a0bcb826.html>. Acesso em: 26 jan. 2012.

Global Appeal 2005. Geneva, 2004b. Disponível em:

<http://www.unhcr.org/4a0ae8276.html>. Acesso em: 26 jan. 2012.

Global Appeal 2006. Geneva, 2005d. Disponível em:

<http://www.unhcr.org/4a0ad61f6.html>. Acesso em: 26 jan. 2012.

Global Appeal 2007. Geneva, 2006b. Disponível em:

<http://www.unhcr.org/4a0a900f6.html>. Acesso em: 26 jan. 2012.

Global Appeal 2008-2009. Geneva, 2007c. Disponível em:

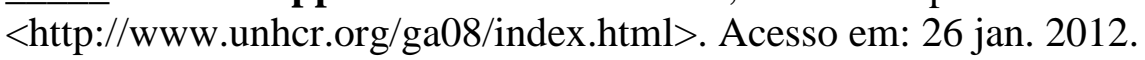

Global Appeal 2009 (Update). Geneva, 2008b. Disponível em:

<http://www.unhcr.org/ga09/index.html>. Acesso em: 26 jan. 2012.

Global Appeal 2010-2011. Geneva, 2009b. Disponível em:

<http://www.unhcr.org/ga10/index.html\#/home>. Acesso em: 26 jan. 2012.

Global Appeal 2011 (Update). Geneva, 2010b. Disponível em:

<http://www.unhcr.org/ga11/index.html\#/home>. Acesso em: 26 jan. 2012. 
Global Consultations: update 31 january 2001. 2001b. Disponível em:

<http://www.unhcr.org/3d6c8c504.html >. Acesso em: 26 jan. 2012.

Handbook on procedures and criteria for determining refugee status under the 1951 Convention and the 1967 Protocol relating to the status of refugee. Geneva, 1992. Disponível em: <http://www.unhcr.org/3d58e13b4.html>. Acesso em: 26 jan. 2012.

.Human rights and refugee protection. Geneva, 1995. Disponível em:

$<$ http://protection.unsudanig.org/data/general/UNHCR-

Human\%20Rights\%20and\%20Refugee\%20Protection\%20(1995).pdf >. Acesso em: 26 jan. 2012.

Refugee status determination: identifying who is a refugee. Self-study module 2. Geneva, 2005b. Disponível em: 〈http://www.unhcr.org/refworld/docid/43141f5d4.html >. Acesso em: 26 jan. 2012.

Statistical Yearbook 2001: trends in displacement, protection and solutions. Geneva, 2002a. Disponível em: <http://www.unhcr.org/4a02e3406.html>. Acesso em: 26 jan. 2012.

Statistical Yearbook 2002: trends in displacement, protection and solutions. Geneva, 2004a. Disponível em: <http://www.unhcr.org/4a07e87d6.html>. Acesso em: 26 jan. 2012.

Statistical Yearbook 2003: trends in displacement, protection and solutions. Geneva, 2005c. Disponível em: <http://www.unhcr.org/42aff7e84.html>. Acesso em: 26 jan. 2012.

Statistical Yearbook 2004: trends in displacement, protection and solutions. Geneva, 2006a. Disponível em: <http://www.unhcr.org/44e96c842.html>. Acesso em: 26 jan. 2012.

Statistical Yearbook 2005: trends in displacement, protection and solutions. Geneva, 2007a. Disponível em: <http://www.unhcr.org/464478a72.html>. Acesso em: 26 jan. 2012.

Statistical Yearbook 2006: trends in displacement, protection and solutions. Geneva, 2007b. Disponível em: <http://www.unhcr.org/478cda572.html>. Acesso em: 26 jan. 2012.

. Statistical Yearbook 2007: trends in displacement, protection and solutions. Geneva, 2008a. Disponível em: <http://www.unhcr.org/4981b19d2.html>. Acesso em: 26 jan. 2012.

. Statistical Yearbook 2008: trends in displacement, protection and solutions. Geneva, 2009a. Disponível em: <http://www.unhcr.org/4bcc5bb79.html>. Acesso em: 26 jan. 2012.

Statistical Yearbook 2009: trends in displacement, protection and solutions. Geneva, 2010a. Disponível em: 〈http://www.unhcr.org/4ce532ff9.html>. Acesso em: 26 jan. 2012.

Statistical Yearbook 2010: trends in displacement, protection and solutions. Geneva, 2011. Disponível em: <http://www.unhcr.org/4ef9cc9c9.html>. Acesso em: 26 jan. 2012.

UNHCR and Human Rights: a policy paper resulting from deliberations in the Policy Committee on the basis of a paper prepared by the Division of International Protection. Geneva, 1997. Disponível em: <http://www.unhcr.org/refworld/docid/3ae6b332c.html>. Acesso em: 26 jan. 2012. 